\title{
Early Jurassic Caenogastropoda and Architectibranchia from the Neuquén Basin, Argentina
}

\author{
Mariel Ferrari ${ }^{1,2}$ \\ ${ }^{1}$ Instituto Patagónico de Geología y Paleontología (IPGP-CCT-CENPAT), Bvd. Brown 2915, U9120CD, Puerto Madryn-Chubut, Argentina \\ 〈mferrari@ cenpat-conicet.gob.ar〉 \\ ${ }^{2}$ Consejo Nacional de Investigaciones Científicas y Técnicas (CONICET)
}

\begin{abstract}
Early Jurassic marine gastropods are well represented in Argentina by three major taxa: Vetigastropoda, Caenogastropoda and Architectibranchia (= Opisthobranchia). The present paper aims at the description of six new caenogastropod species and one new architectibranch species from the Early Jurassic marine deposits of the Neuquén Basin, namely Procerithium subimbricatum n. sp., Microschiza weaveri n. sp., Naricopsina aequabilis n. sp., Naricopsina ballentae n. sp., Pictavia rothi n. sp., Oonia acuta n. sp., and Cylindrobullina brevispira n. sp. Seven other caenogastropods are reported for the first time in the area, including Cryptaulax redelii Ferrari, Procerithium nulloi (Ferrari), Rhabdocolpus patagoniensis (Ferrari), Rhabdocolpus? sp., Pseudomelania feruglioi Ferrari, Pseudomelania aff. baugieriana (d'Orbigny), and Anulifera chubutensis Ferrari, extending their palaeobiogeographical distribution to the Andean region of Argentina during the Early Jurassic. Caenogastropods such as Globularia catanlilensis (Weaver) and Microschiza? americana (Möricke), and the architectibranch species Striactaeonina transatlantica (Behrendsen) and Cylindrobullina ovata (Behrendsen) are redescribed and discussed based on new specimens from the type and other localities. The new fossils described here expand the known diversity of the gastropod faunas in the Early Jurassic of Argentina and contribute to the paleontological knowledge of the group in the Mesozoic of South America.
\end{abstract}

\section{Introduction}

Updated knowledge of Early Jurassic marine gastropods from the Andean region of Argentina has been provided recently by Ferrari $(2009,2011,2012,2013,2014,2015)$ for the Chubut Basin, and by Damborenea and Ferrari (2008) and Ferrari et al. (2014, 2015) for the Neuquén Basin. Those contributions supplied an updated systematic database of the gastropod taxonomic composition in the region. These studies indicate that gastropods are well represented in the Early Jurassic of Argentina by three major taxa: Vetigastropoda, Caenogastropoda and Architectibranchia (= Opisthobranchia), although Patellogastropoda Lindberg, 1986 and other representatives of Heterobranchia Haszprunar, 1988 are also present but less commonly found and less diversified in the marine deposits. The systematic and palaeobiogeographical knowledge about Argentinean vetigastropods was discussed recently by Ferrari (2015). The present paper is focused on the Caenogastropoda and Architectibranchia species and attempts to improve and update the systematic knowledge of these particular taxa in the Neuquén Basin, and to reassess the Jurassic gastropod collections currently existing in Argentina, supplying new evidence on Early Jurassic marine gastropods in South America. Nineteen caenogastropod and architectibranch species are reported here from the Neuquén Basin, among which seven are new to science; these are Procerithium subimbricatum n. sp., Microschiza weaveri n. sp., Naricopsina aequabilis n. sp., Naricopsina ballentae n. sp., Pictavia rothi n. sp., Oonia acuta n. sp., and Cylindrobullina brevispira n. sp. Seven other caenogastropods are testified for the first time in the area including Cryptaulax redelii Ferrari, Procerithium nulloi (Ferrari), Rhabdocolpus patagoniensis (Ferrari), Rhabdocolpus? sp., Pseudomelania feruglioi Ferrari, Pseudomelania aff. baugieriana (d'Orbigny), and Anulifera chubutensis Ferrari, extending their known palaeobiogeographical distribution in the Andean region of Argentina. The occurrences of Globularia catanlilensis (Weaver), Microschiza? americana (Möricke), Procerithium bodenbenderi (Behrendsen), and the architectibranchs Striactaeonina transatlantica (Behrendsen) and Cylindrobullina ovata (Behrendsen) is confirmed based on new material from the type and other localities in the Early Jurassic marine beds at the Neuquén Basin.

\section{Geologic setting}

A geological framework of the Argentinean Neuquén and Chubut basins was summarized by Ferrari (2015, p. 920, see references therein). The gastropod material described below comes from several localities in the Neuquén Basin, at the Neuquén and Mendoza provinces (Fig. 1.2).

In Mendoza Province, Hettangian to Toarcian sediments of the Atuel-western Malargüe depocentre contain gastropods at Arroyo Malo (Fig. 1.2, locality AML-N), Arroyo El Pedrero (Fig. 1.2, locality APR-N), Arroyo Las Chilcas (Fig. 1.2, locality ACHL-N), Puesto Araya (Fig. 1.2, locality PAY-N), Paso del Portezuelo Ancho (Fig. 1.2, locality PA-N), Arroyo del 

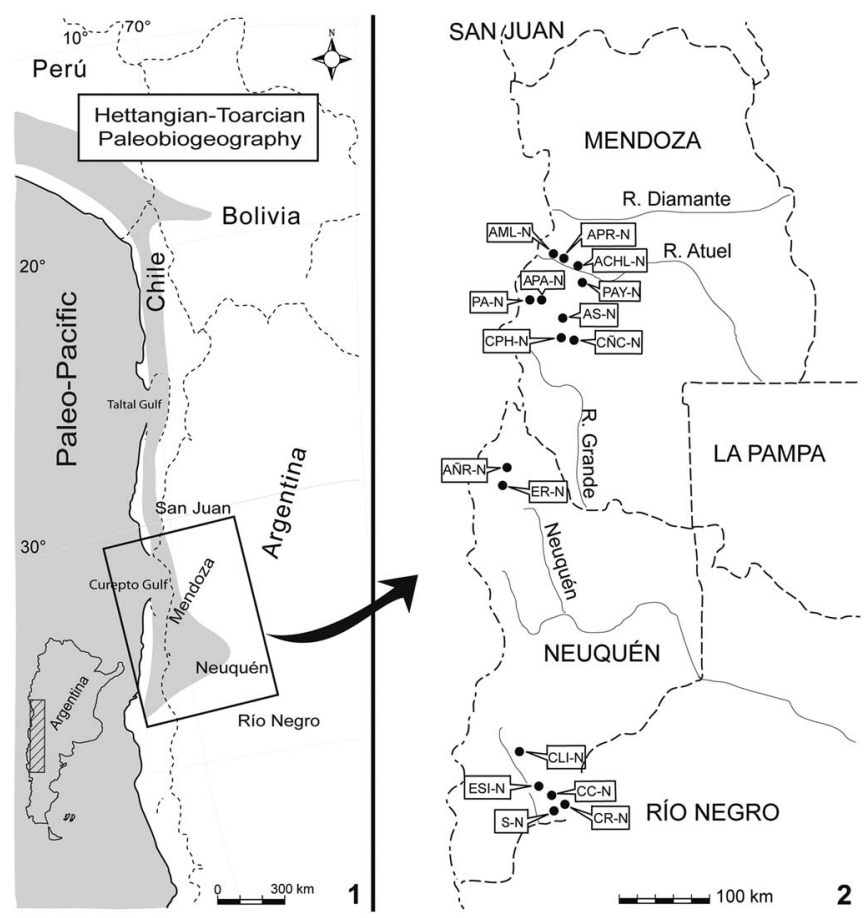

Figure 1. (1) Map of the western part of South America showing the study area at the Neuquén Basin during the Hettangian-Toarcian. (2) Location map of the main localities with gastropod species described in the text. AML-N = Ayo. Malo; APR-N = Ayo. El Pedrero; ACHL-N = Ayo. Las Chilcas; PAY-N $=$ Puesto Araya; PA-N = Paso del Portezuelo Ancho; APA-N = Arroyo del Portezuelo Ancho; AS-N = Ayo. Serrucho; CPH-N = Co. Puchenque; $\mathrm{CN} C-\mathrm{N}=\mathrm{Cañada}$ Colorada; AÑR-N = Ayo. Ñiraico; ER-N = Estación Rajapalo; CLI-N = Catán Lil; ESI-N = Ea. Santa Isabel; CC-N = Carrán Curá; CR-N = Co. Roth; S-N = Sañicó $\quad$ (modified from Ferrari, 2015).

Portezuelo Ancho (Fig. 1.2, locality APA-N), Arroyo Serrucho (Fig. 1.2, locality AS-N), Cerro Puchenque (Fig. 1.2, locality CPH-N), and Cañada Colorada (Fig. 1.2, locality CÑC-N). Gastropods were also found in Pliensbachian-Toarcian deposits in the Cuyo Group beds within the Neuquén embayments in northern and southern Neuquén Province, at Arroyo Niraicó (Fig. 1.2, locality AÑR-N), Estación Rajapalo (Fig. 1.2, locality ER-N), Catán Lil (Fig. 1.2, locality CLN-N), Estancia Santa Isabel (Fig. 1.2, locality ESI-N), Carrán Curá (Fig. 1.2, locality CC-N), Cerro Roth (Fig. 1.2, locality CR-N), and Sañicó (Fig. 1.2, locality S-N).

\section{Materials and methods}

The gastropod material here described was collected by S. Damborenea, A. Riccardi, M. Manceñido, J. Echevarría (Museo de Ciencias Naturales de La Plata), S. Lanés (Universidad de Buenos Aires), C. Gulisano (YPF), and the present author during several fieldtrips to the Neuquén Basin. Stratigraphical sections for most of the localities yielding gastropods in the Neuquén Basin were described by Damborenea et al. (1975), Damborenea (1987), and Damborenea and Manceñido (2005). Specimens described here were found in the Early Jurassic at different stratigraphic levels, spanning the Hettangian to early Toarcian, according to the current ammonite biozonation (Riccardi 2008a, b; Riccardi et al., 2011).

Most of the Argentinean gastropod material described here is housed in the Museo de Ciencias Naturales de La Plata (MLP) collection and in the Museo Paleontológico Carmen Funes, Plaza Huincul (MCF-PIPH). Material described by Weaver (1931), which is currently housed in the Burke Museum of Natural History and Culture (Seattle, USA) (BM), was revised and casts are kept in the La Plata Museum collections. Additional gastropod material described by Gründel (2001a) from the Early Jurassic of Chile and Argentina which is currently stored at the Museum für Naturkunde, Berlin (MB.Ga.) was also revised, subsequently compared with the specimens here analyzed and included in this paper. The Argentinean specimens were prepared by technical staff (Leandro Canessa and Roberto Pfeiffer) at the MEF laboratory, and by Santiago Bessone at the CENPAT laboratory. Latex cast were obtained from specimens preserved as external moulds and the material was coated with ammonium chloride to enhance sculpture details for photography. Photographs were taken using a digital camera, and using scanning electronic microscopy (SEM) at ALUAR (Pto. Madryn).

Repositories and institutional abbreviations.-MLP $=$ Museo de Ciencias Naturales de La Plata, Buenos Aires, Argentina; MCF-PIPH = Museo Paleontológico Carmen Funes, Plaza Huincul, Neuquén, Argentina; MB.Ga. = Museum für Naturkunde Humboldt-Universität zu, Berlin, Germany; MPEF-PI = Museo Paleontológio Egidio Feruglio; BM = Burke Museum of Natural History and Culture, Seattle, USA; CENPAT $=$ Centro Nacional Patagónico, Puerto Madryn, Chubut, Argentina; ALUAR = Aluminio Argentino, Puerto Madryn, Chubut, Argentina; YPF $=$ Yacimientos Petrolíferos Fiscales.

\section{Systematic paleontology}

Superorder Caenogastropoda Cox, 1960

Order Sorbeoconcha Ponder and Lindberg, 1997

Suborder Cerithiomorpha Golikov and Starobogatov, 1975

Superfamily Cerithioidea Fleming, 1822

Family Procerithiidae Cossmann, 1906

Subfamily Procerithiinae Cossmann, 1906

Genus Cryptaulax Tate, 1869

Figure 2. (1-7) Cryptaulax redelii Ferrari, 2012. (1) MLP 35459, lateral view. (2-7) MLP 12193/a. (2, 3) Lateral and apertural views, (4, 5) lateral views, $(6,7)$ ornament detail. (8-10) Procerithium nulloi (Ferrari, 2009). (8) MLP 35464, lateral view. (9) MLP 12163, lateral and apertural view. (10) MCF-PIPH 567, lateral view. (11) Procerithium bodenbenderi (Behrendsen, 1891), MLP 35462, lateral view. (12, 13) Procerithium subimbricatum n. sp., MLP 35460, holotype, lateral views. (14-17) Procerithium (Rhabdocolpus) patagoniensis Ferrari, 2012, MLP 35465. (14-17) Lateral views; (18) Rhabdocolpus? sp., MLP 35517, lateral view. (19-27) Microschiza weaveri n. sp. (19, 20) MLP 25020 (cast of BMNH 44091/SA1029), paratype, lateral views. (21-24) MLP 35468, holotype. (21) lateral view; (22, 23) lateral and apertural views; (24) apertural detail. (25-27) MLP 35467, paratype. (25) Lateral view; (26) apical view; (27) lateral and apertural. (28) Microschiza? americana, MLP 25021 (cast of BMNH 269/SA1029) lateral view. (29-35) Pseudomelania feruglioi Ferrari, 2013. (29) MLP 35472, lateral and apertural views. (30, 31) MLP 35473, lateral and apertural views. (32) MLP 35469, lateral and apertural view. (33) MLP 19638, lateral view. (34-37) MLP 35459. (34) Three specimens in lateral views; (35) juvenile and mature teleoconch in latera view; (36) juvenile teleoconch detail; (37) basal detail. (38, 39) Pseudomelania aff. baugieriana (d'Orbigny, 1850) MLP 12174, fragmentary specimen in lateral views. (40) Anulifera chubutensis Ferrari, 2013, MLP 35516, lateral view. 


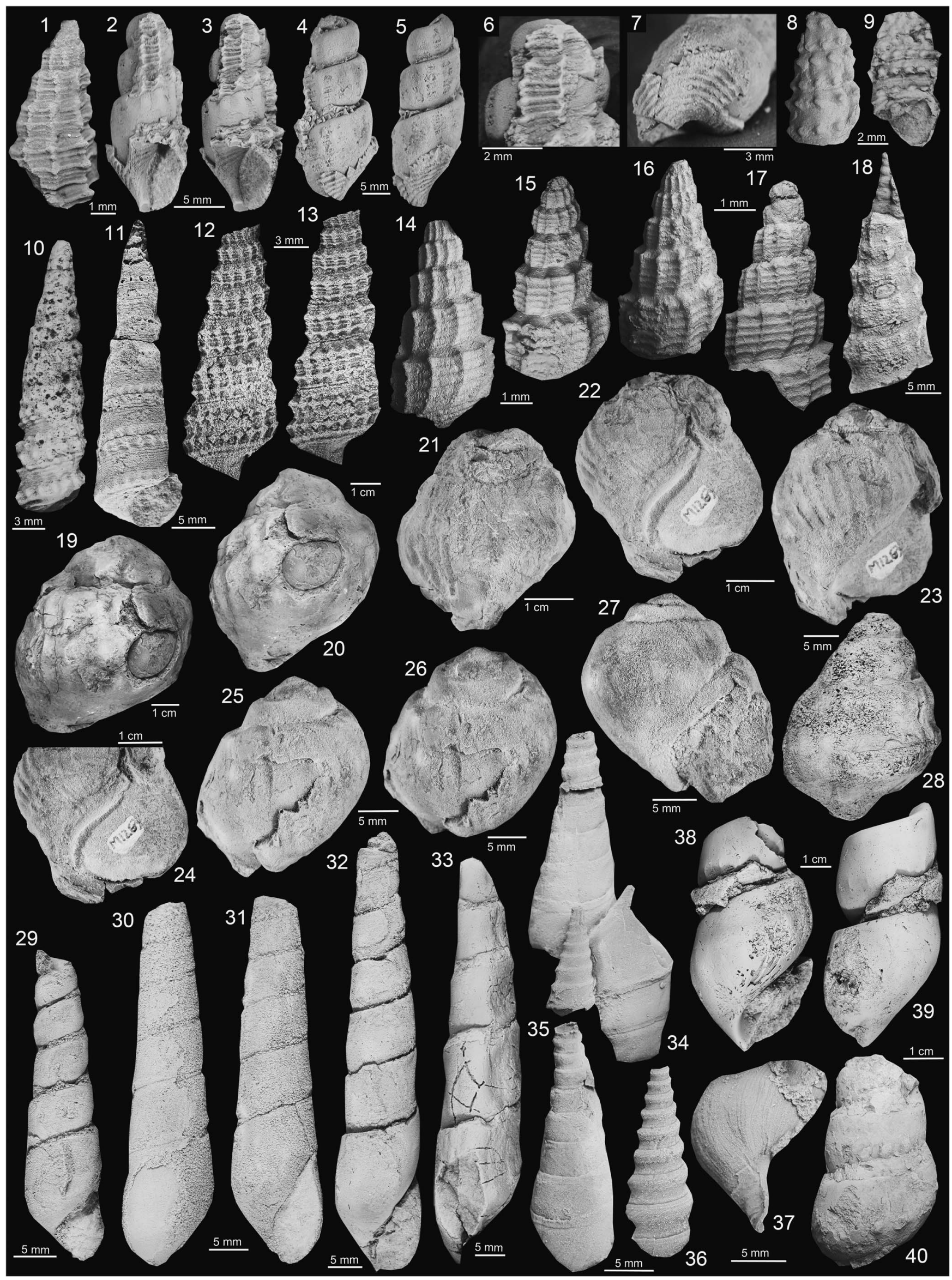


Type species.-Procerithium (Xystrella) protortile Cox, 1965, pro Cerithium tortile Hébert and Eudes-Deslongchamps, 1860, from the Middle Jurassic (Callovian) of France.

Occurrence.-Cosmopolitan; Upper Triassic-Lower Cretaceous.

Cryptaulax redelii Ferrari, 2012

Figure 2.1-2.7

2012 Cryptaulax redelii Ferrari; Ferrari, p. 327, fig. 2I-K.

Holotype.-MPEF-PI 3508, from Lomas Occidentales, Chubut Province, Argentina in the Mulanguiñeu Formation (Ferrari, 2012, fig. 2I-K).

Occurrence.-Cerro Roth and Estación Rajapalo, Pliensbachian, Neuquén Province. Previously known from Lomas Occidentales, Pliensbachian-Toarcian, Chubut Province, Argentina (Ferrari, 2012).

Description.-See original description of the species in Ferrari (2012, p. 327).

Materials.-MLP 12193a/b, 35459; three specimens preserved as external moulds.

Dimensions $(\mathrm{mm})$. - MLP 12193/a: height $=17.0 ;$ width $=$ 8.7; apical angle $=47^{\circ} *$ MLP $12193 / \mathrm{b}$ : height $=16.2$; width $=9.4$; apical angle $=42^{\circ} *$ MLP 35459: height $=8.7$; width $=3.9$; apical angle $=51^{\circ} . *$ fragmentary data

Remarks.-According to the diagnosis proposed by Ferrari (2012, p. 327), the specimens here analyzed certainly represent members of Cryptaulax redelii. Ferrari (2012, p. 327) reported this species from the Early Jurassic (PliensbachianToarcian) of the Chubut Province. Cryptaualx weaveri Ferrari and Damborenea (2015, p. 634, fig. 2. 16-19), from the early Bajocian of the Neuquén Basin, differs from $C$. redelii in having a high number of primary and secondary spiral cords on mature teleoconch whorls, and more conspicuous nodes at the crossing points of spiral and axial elements.

For comparison with other similar Cryptaulax species from Argentina and western Tethys, see Ferrari (2012).

\section{Genus Procerithium Cossmann, 1902}

Type species.-Procerithium quinquegranosum Cossmann, 1902, from the Early Jurassic (Hettangian) of France.

Occurrence.-Europe, Africa, New Zealand, Asia, Antarctica (?), and South America; Lower Jurassic (Hettangian)-Lower Cretaceous (Barremian).

Remarks.-Representatives of Procerithium were characterized by Gründel (1999). According to the author, this genus groups "slender shells, with numerous whorls, outline of the whorls straight to convex, with distinct sutures, on later whorls the number of spiral and axial elements is variable with nodes at the crossing points, base weakly convex, angulated to the upper part of the whorls, with one strong spiral at the periphery and 1-2 weaker spirals toward the centre." In the present paper, the diagnosis of Gründel (1999) is followed.

Procerithium nulloi (Ferrari, 2009)

Figure 2.8-2.10

2009 Cryptaulax nulloi Ferrari, p. 457, fig. 3F-H.

2012 Procerithium nulloi (Ferrari); Ferrari, p. 328, figs. 2L-T, $4 \mathrm{~A}-\mathrm{F}$.

Holotype.-MPEF-PI 1870, from Puesto Currumil, Chubut Province, Argentina in the Osta Arena Formation (Ferrari, 2012, figs. 2P-Q).

Occurrence.-Cerro Roth and Subida a Sañicó, Pliensbachian, Neuquén Province, Argentina. Previously known from Puesto Currumil and Lomas Occidentales, Pliensbachian-Toarcian, Chubut Province, Argentina (Ferrari, 2009, 2012).

Description.-See original description of the species in Ferrari (2009, p. 457; 2012, p. 328).

Materials.-MLP 12163, 35464, MCF-PIPH 567; five fragmentary and recrystallized specimens; one external mould.

Dimensions $(\mathrm{mm})$. - MCF-PIPH 567: height $=22.7 ;$ width $=$ 6.4; apical angle $=26^{\circ}$. MLP 35464-1: height $=11.0$; width $=3.3$; apical angle $=28^{\circ}$. MLP 35464-2: height $=11.5$; width $=4.0$. MLP 35464-3: apical angle $=36^{\circ}$.

Remarks.-The specimens reported here fits with the characterization of the species proposed by Ferrari (2009, p. 457, fig. 3F-H, as Cryptaulax nulloi; Ferrari, 2012, p. 328, figs. 2L-T, $4 \mathrm{~A}-\mathrm{F}$ ), from the Early Jurassic of the Chubut Province, Argentina.

For comparisons of Procerithium nulloi with other similar species of South America and western Tethys, see Ferrari (2009, 2012).

Procerithium bodenbenderi (Behrendsen, 1891) new combination

Figure 2.11

1891 Cerithium bodenbenderi Behrendsen, p. 382, pl. 22, fig. 4. 1922 Cerithium bodenbenderi Behrendsen; Behrendsen, p. 168, pl. 1, fig. 4.

Holotype.-A well-preserved specimen, originally described by Behrendsen (1891) from the Early Jurassic of Paso del Portezuelo Ancho, Mendoza Province, Argentina (Behrendsen, 1891 , p. 382, pl. 22, fig. 4). Behrendsen's original material, which should be housed at Göttingen, Germany, could not be examined.

Occurrence.-Cerro Puchenque and Paso del Portezuelo Ancho, Pliensbachian, Mendoza Province, Argentina. 
Description.-Dextral, turriculate, high-spired, and mediumsized shell. The teleoconch comprises up to 10 (or more) flattened whorls, with a height of $34.0 \mathrm{~mm}$ and a width of $9.0 \mathrm{~mm}$. The apex forms an angle of $30^{\circ}$, although earliest teleoconch whorls are missing in the available specimens. Suture is deeply impressed in a spiral furrow. The ornament is spiral predominantly, consisting of one to two primary and strongly nodular cords located in adapical and abapical position on the outer face; a second order of weaker spiral cords appear between the primary ones, and in the middle of mature whorls are present in numbers of 12-14. The presence of two strong nodular spiral keels bordering the sutures gives the outer face of the shell a slightly concave appearance. The base is flat, ornamented by weak spiral cords; the aperture is holostomatous and subcircular.

Materials.-MLP 35462, 35463; two fragmentary and recrystallized specimens.

Dimensions $(\mathrm{mm})$. - MLP 35462: height $=34.0$; width $=9.0$; apical angle $=40^{\circ}$. MLP 35463: height $=43.0$; width $=10.5$.

Remarks.-Procerithium bodenbenderi was originally described by Behrendsen (1891) under the genus Cerithium. This species is here reassigned to the genus Procerithium, following the updated characterization of Gründel (1999) (see also Ferrari, 2012).

Behrendsen's species is very similar in ornament to Procerithium nulloi (Ferrari). The differences between both species were clearly stated out by Ferrari (2012): "Procerithium nulloi is very similar to Cerithium bodenbenderi Behrendsen (1891, p. 382, pl. 22, fig. 4) from the Early Jurassic of Mendoza Province (Argentina). They share the same general shell morphology, with a high-spired shell, slightly concave whorls and nodose rows bordering the sutures on each mature whorl. However, C. bodenbenderi is much larger, has more conspicuous nodes and a greater number (12-14) of spiral ribs on mature whorls."

$P$. bodenbenderi has a paleogeographical distribution limited to the Mendoza Province, whereas the northernmost occurrence of $P$. nulloi in the Andean region of Argentina reaches the southern Neuquén Province.

\section{Procerithium subimbricatum new species} Figure 2.12-2.13

Holotype.-MLP 35460; one specimen preserved as external mould.

Diagnosis.-Sub-imbricate, turriculate; subhorizontal sutural ramp; spiral ornament predominant on the outer face; adult teleoconch with 2 primary spiral cords; 2 secondary spirals cords between the primary ones on mature whorls; nodes at the crossing points of spiral and axial elements.

Occurrence.-Paso del Portezuelo Ancho, late Pliensbachian, Mendoza Province, Argentina.
Description.-Dextral, turriculate, medium-sized and highspired shell. The apex is broken and earliest teleoconch whorls are missing. The protoconch is not preserved. The fragmentary teleoconch has a height of $18.2 \mathrm{~mm}$ and a width of $7.7 \mathrm{~mm}$, and consists of seven slightly imbricated whorls. The ramp is flat to inclined approximately $45^{\circ}$ from sutures; toward the outer face the whorl become flat and vertical. Suture is clearly impressed in a spiral furrow. The shell is ornamented by spiral, axial and nodular elements. The ramp bears weak and regularly spaced axial ribs. The outer face of whorls is ornamented by four regularly spaced spiral cords; two primary cords are located in an adapical and abapical position on the outer face; two other secondary cords are median and located between the primary ones. The primary spiral cords become stronger toward mature growth stages. Strong and regularly spaced axial ribs intercept the spiral elements on the outer face forming nodes at the crossing points. Nodes are more conspicuous and acute at the intersection with the primary spiral cords. On last whorl, nodes are even stronger and a third spiral and nodular cord appears below the abapical one, delimiting the base. The base is flat to slightly convex, ornamented by 1 spiral cord. The apertural characters are missing.

Etymology.-Referred to the strongly sub-imbricated teleoconch whorls.

Remarks.-In the present paper, the concepts of Gründel (1999, 2003) and Schulbert and Nützel (2013) are followed to include the specimen here described into the genus Procerithium. The variable number of spiral and axial elements on mature whorls, together with the presence of nodes at the crossing points, are considered as the main diagnostic characters; however, none of the protoconch features are preserved in the available material.

Procerithium subimbricatum n. sp. differs from Procerithium nulloi (Ferrari, 2009; see above) in being larger, having an imbricate outline shell, a sub-horizontal sutural ramp, and axial ribs on the shell surface. P. subimbricatum resembles Procerithium (Rhabdocolpus) patagoniensis Ferrari; however, the new species has a sub-imbricate shell outline, a more reticulate ornament pattern, secondary spiral cords on the middle of whorls, and more developed nodes at the crossing points of axial and spiral elements.

\section{Genus Rhabdocolpus Cossmann, 1906}

Type species.—Melania scalariformis Deshayes, 1830 from the Middle Jurassic of France.

Occurrence.-Europe, New Zealand, Antarctica and South America; Late Triassic?-Late Jurassic.

Remarks.-The characterization of Rhabdocolpus was stated out by Gründel (1999) and Bandel et al. (2000). Both authors included within Rhabdocolpus high-spired and flattened to slightly convex outline shell, with a horizontal to strong sloping sub-sutural ramp, opisthocyrt axial ribs on the teleoconch, forming nodes at the crossing point with spiral elements, and base with an adapical channel and lacking abapical notch. The genus is common in the Jurassic of Europe, and Haas (1953) 
reported the first occurrence of Rhabdocolpus in the Upper Triassic of the Pucará group (South America). In the present paper, the diagnosis of Gründel (1999) and Bandel et al. (2000) are followed.

\section{Rhabdocolpus patagoniensis (Ferrari, 2012) new combination \\ Figure 2.14-2.17}

2009 Cryptaulax cf. damboreneae Ferrari, p. 454, fig. 3E.

2012 Procerithium (Rhabdocolpus) patagoniensis Ferrari, p. 329, figs. 4G-P, 5A-K.

2015 Procerithium (Rhabdocolpus) patagoniensis Ferrari; Ferrari, p. 84, fig. 5O-R.

2015 Procerithium (Rhabdocolpus) patagoniensis Ferrari; Ferrari and Bessone, p. 353, fig. 3L-M.

Holotype.-MPEF-PI 3517, from Lomas Occidentales, Chubut Province, Argentina in the Mulanguiñeu Formation (Ferrari, 2012, figs. 4G-J).

Occurrence.-Arroyo Las Chilcas, Río Atuel region, late Sinemurian (Orthechioceras-Paltechioceras Zone), Mendoza Province, Argentina. Previously known from Lomas Occidentales and La Casilda, Pliensbachian-Toarcian, Chubut Province, Argentina (Ferrari, 2012).

Description.-Dextral, turriculate, small-sized and high-spired shell. The protoconch is not preserved. The teleoconch has a mean height of $4.7 \mathrm{~mm}$ and a mean width of $2.6 \mathrm{~mm}$, and consists of six flattened to slightly convex whorls. The mean apical angle is of $59^{\circ}$, although earliest teleoconch whorls are missing. A narrow sub-sutural ramp gives the periphery of the shell a step-like outline. Suture is weakly impressed. The axial ornament is predominant on all teleoconch whorls and consists of opisthocyrt to straight ribs, which run from suture to suture. The axial ribs are strong and slightly orthocline on juvenile whorls, becoming more spaced and opisthocyrt toward mature growth stages. The axial elements intercept five to six regularly spaced spiral cords on teleoconch whorls, forming nodes at the crossing points. The nodes on the adapical spiral cords are spiny and stronger than the others. The base is convex and ornamented by four visible regularly spaced spiral cords. The aperture is fragmentary and subcircular.

Materials.-MLP 35465, 35466; three specimens preserved as negative moulds.

Dimensions $(\mathrm{mm})$. - MLP 35465-1: height $=4.6$; width $=2.5$; apical angle $=57^{\circ}$. MLP 35465-2: height $=4.9 ;$ width $=3.0$; apical angle $=60^{\circ}$. MLP 35466: height $=4.7$; width $=2.5$; apical angle $=60^{\circ}$.

Remarks.-Ferrari (2012, p. 329) and Ferrari and Bessone (2015, p. 353) described this species as Procerithium (Rhabdocolpus) patagoniensis from the Early Jurassic (Pliensbachian-Toarcian) of the Chubut Province. Here it is transferred to the genus Rhabdocolpus following the diagnosis of Gründel (1999) and Bandel et al. (2000). Representatives of
Rhabdocolpus have been reported recently from the early Bajocian of the Neuquén Basin with the species Rhabdocolpus (Infacerithium) excavatus Ferrari and Damborenea (2015, p. 635, fig. 2.20-22). The Bajocian form, however, has a less step-like outline shell with more convex teleoconch whorls, a less horizontal sub-sutural ramp, and more rounded and conspicuous nodes at the crossing point of spiral and axial ribs. Cryptaulax cf. damboreneae Ferrari (2009, p. 545, fig. 3E), from the early Toarcian of Cerro Puchenque locality, was originally described by the author as a conespecific species of Cryptaulax damboreneae; however, it has a larger shell, orthocline to slightly opistocline axial ribs, and stronger spiral cords. Cryptaulax cf. damboreneae is here included as a synonymous of Rhabdocolpus patagoniensis (Ferrari, 2012) (see above).

For comparisons with other similar procerithiids species, see Ferrari (2012).

\section{Rhabdocolpus? sp. \\ Figure 2.18}

Occurrence.-Cerro Puchenque, Pliensbachian, Mendoza Province, Argentina.

Description.—Dextral, turriculate, high-spired, and mediumsized shell. The fragmentary teleoconch has a height of $23.2 \mathrm{~mm}$ and a width of $7.5 \mathrm{~mm}$, and consists of ten step-like whorls. The sub-sutural ramp is narrow and horizontal, and sutures are weakly incised in a spiral furrow on the subsutural area. The upper portion of whorls is delimited by a convex, nodular swollen belt, which gives the periphery of the shell a step-like appearance. Nodes are conspicuous, rounded, and more or less spaced. The nodular swollen belt also bears fine, separated, and almost imperceptible spiral cords. Whorls become flat to slightly concave toward the outer face. Basal and apertural characters are missing.

Materials.-MLP 35517; one fragmentary specimen.

Remarks.-The single specimen described is assigned to Rhabdocolpus based on the presence of a high-spired shell and an horizontal sub-sutural ramp; however, the typical axial ribs on the whorls flank intercepted by spiral cords and forming nodes at the crossing points, and the adapical channel on base are not visible in the available material; thus, the specimen is left in open nomenclature. Rhabdocolpus? sp. differs from Rhabdocolpus patagoniensis in being larger and in lacking the strong opisthocyrt axial ribs intercepted by spiral cords on the shell surface.

Suborder Hypsogastropoda Ponder and Lindberg, 1997

Superfamily Littorinoidea Gray, 1840

Family Purpurinidae Zittel, 1895

Genus Microschiza Gemmellaro, 1878

Type species.—Turbo philenor d'Orbigny, 1847, from the Early Jurassic (Sinemurian) of France. 
Occurrence.-Early Jurassic-Early Cretaceous; Europe, Japan, South America.

Remarks.—Microschiza was originally proposed by Gemmellaro (1878) as a subgenus of Chemitzia, to distinguish sub-imbricated and bucciniform shells, with a low spire, aperture oval, strongly expanded abapically and acute posteriorly, and ornamented by sinusoidal axial ribs. Later authors (Cossmann, 1909; Delpey, 1937; Wenz, 1938; Kase, 1984) included Microschiza within Pseudomelaniidae, even though Fischer and Weber (1997) assigned the genus to the family Purpurinidae, on the basis of its similarities with the genus Purpurina d'Orbigny, 1850. However, the systematic position of Microschiza still remains unclear. In the present paper, the proposal of Fischer and Weber (1997) is followed.

The genus Microschiza is not a very common genus within the Mesozoic gastropod faunas, and has a relatively narrow distribution range, being only mentioned in Early Jurassic and Early Cretaceous deposits of Europe and Japan, respectively. The new species described below represent the first occurrence of Microschiza in the Jurassic of Argentina.

\section{Microschiza weaveri new species}

Figure 2.19-2.27

1931 Amberleya cf. americana Möricke; Weaver: p. 370. (pars) 2001a Microschiza sp. Gründel, p. 60, pl. 4, figs. 15-16.

Holotype.-MLP 35468; one recrystallized specimen.

Paratypes.-MLP 35467; one recrystallized specimen. BMNH 44091/SA1029 of Weaver's collection and originally assigned by Weaver (1931) to Amberleya cf. Americana (cast MLP 25020).

Diagnosis.-Globular and slightly bucciniform shell; convex whorls; sutural ramp narrow and horizontal; prosocyrt to sinusoidal axial ribs; aperture holostomatous and oval; outer lip strongly convex; columellar lip thickened.

Occurrence.-Catán Lil, Plienbachian, Neuquén Province, Argentina (Weaver collection); Arroyo Las Chilcas, Río Atuel region, late Sinemurian (Orthechioceras-Paltechioceras Faunule), Mendoza Province; Cerro de Cuevitas, Early Jurassic (Sinemurian), Chile (Gründel, 2001a).

Description.-Dextral, globular to slightly bucciniform, gradate, medium- to large-sized, and low-spired shell. The protoconch is not preserved. The teleoconch has a mean height of $41.6 \mathrm{~mm}$ and a mean width of $33.6 \mathrm{~mm}$, and consists of three to four strongly convex whorls, but slightly concave in the middle, and last whorl greatly expanded. The apex forms an angle of $122^{\circ}$. The sub-sutural ramp is narrowly horizontal. Suture is incised in a concave furrow. The axial ornament is predominant and visible on last whorl, and consists of prosocyrt to sinusoidal and strong axial ribs. The base is strongly convex to angular and smooth. The aperture is holostomatous and forms an adapical notch. The outer lip is convex and the columellar lip thickened as a callus. The basal lip is expanded abapically.
Etymology.-Dedicated to C. Weaver, who contributed to the paleontological knowledge of Jurassic marine gastropods from the Andean region of Argentina and who collected one of the paratypes.

Materials.-MB.Ga.785; one recrystallized teleoconch. Specimen originally assigned by Gründel (2001a) to Microschiza sp., from the Early Jurassic (Sinemurian) of Chile.

Dimensions $(\mathrm{mm})$.-MLP 35468 , holotype: height $=41.4$; width $=32.2$; apical angle $=122^{\circ}$. MLP 35467, paratype: height $=24.0 ;$ width $=20.2 ;$ apical angle $=115^{\circ}$. MLP 25021, paratype: height $=64.5$; width $=55.0$; apical angle $=$ 131 . MB.Ga.785: height $=36.6 ; \quad$ width $=27.0 ; \quad$ apical angle $=122^{\circ}$.

Remarks.-The material here described shows the diagnostic characters of Microschiza, such as bucciniform and subimbricate shell, with the ornament consisting on sinusoidal axial ribs or furrows, oval aperture.

The type species Microschiza philenor (d'Orbigny) (Fisher and Weber, 1997, p. 128, pl. 23, figs. 22-23), from the Early Jurassic (Sinemurian) of France, is smaller than the Argentinean form, has a rather higher-spired shell with a more acute apex; a more gradate shell shape; a more developed ornament pattern with axial and spiral elements forming nodes at intersections points.

The Cretaceous species, Microschiza japonica (Nagao) (in Kase, 1984; p. 110, pl. 4, figs. 5-7), from the Early Cretaceous of Japan, is similar to M. weaveri $\mathrm{n}$. sp.; however, M. japonica is smaller, has the shell surface sculptured by axial furrows which are variable in strength and number, and its axial furrow usually has nodes on the depression of body whorls. The last character is missing in the Argentinean species. Microschiza aff. heybroeki Delpey, 1940 (Kase, 1984; p. 112, pl. 14, fig. 9a-b), from the Early Cretaceous of Japan, differs from $M$. weaveri in having nodes at the shouldered edge of whorls and in lacking axial ribs.

Microschiza? americana (Möricke, 1894) new combination Figure 2.28

1894 Amberleya americana Möricke: p. 29, pl. 4, fig. 8a-b. 1931 Amberleya cf. americana Möricke; Weaver: p. 370. (pars)

Type material.-Specimens described by Möricke (1894, p. 29, pl. 4, fig. 8a-b) from the Lower Jurassic beds at Mina Amolanas, Chile. The material was originally housed at Strassburg University but could not be examined.

Occurrence.-Catán Lil, Pliensbachian, Neuquén Province, Argentina.

Description.—Dextral, gradate, medium-sized, and moderately high-spired shell. The teleoconch has a height of $51.3 \mathrm{~mm}$ and a width of $39.4 \mathrm{~mm}$. The apex forms an angle of $64^{\circ}$. The horizontal sub-sutural ramp is narrowly developed. The outer face is flat to slightly concave in the middle. On the periphery of whorls, a row of rounded nodes is visible. Suture is weakly incised. The base is flat to angular 
and slightly concave. The aperture is missing. The columellar lip is thickened.

Materials.-Cast MLP 25021 (original material BMNH 269/SA1029 of Weaver's collection); one fragmentary specimen.

Remarks. - The material here analyzed was assigned by Weaver (1931) to Amberleya cf. americana, although it seems to be a member of Microschiza, because it has a bucciniform and subimbricated shell shape. However, the prosocyrt and sinusoidal axial ribs, together with the strongly oval aperture, characteristic of Microschiza, are not visible in the present material, and thus it is left in open nomenclature. Ferrari (2009) stated out that Amberleya itself is of rather disputable identity, and that descriptions and illustrations available in Möricke (1894, p. 29, pl. 4, fig. 8a-b) show that Amberleya americana differs significantly from the type species Amberleya bathonica Cox and Arkell, 1950 (see Ferrari et al., 2014, fig. 2). Ferrari et al. (2014) discussed the systematic status of the genus Amberleya and restricted the usage of the name Amberleya to shells with small umbilicus, a single abapical keel and adapical spiral cord, ornamented by blunt nodes and smooth base; this restricts it largely to the type species A. bathonica.

Microschiza? americana (Möricke, 1894) differs from Microschiza weaveri in having a slightly more gradate and higher-spired shell, narrower apical angle, less convex whorls, more developed nodular elements, and lacking sinusoidal and prosocyrt axial ribs.

Order Ptenoglossa Gray, 1853

Superfamily Pseudomelanoidea R. Hornes, 1884

Family Pseudomelaniidae R. Hornes, 1884

Genus Pseudomelania Pictet and Campiche, 1862

Type species.-Pseudomelania gresslyi Pictet and Campiche, 1862 , by subsequent designation by Wenz (1938); from the Lower Cretaceous (Neocomian) of Switzerland.

Occurrence.-Triassic-Cretaceous (Kaim, 2004). Europe, Asia, Africa, Madagascar, New Zealand and America.

\section{Pseudomelania feruglioi Ferrari, 2013}

Figure 2.29-37

2013 Pseudomelania feruglioi Ferrari, p. 582, figs. 2F-I, $3 \mathrm{~A}-\mathrm{D}$.

?2015 Pseudomelania feruglioi Ferrari; Ferrari and Bessone, p. 354 , fig. 30 .

Holotype.-MPEF-PI 4155, from Lomas Occidentales, Chubut Province, Argentina in the Mulanguiñeu Formation (Ferrari, 2013, fig. 2F).

Emended diagnosis.-Dextral, anomphalous and turriculate shell; teleoconch up to ten whorls; juvenile teleoconch slightly convex or step-like with a convex swollen belt in the adapical sutural area; mature teleoconch with a strong adapical spiral keel on each whorl; opisthocline growth lines on the middle of mature whorls, and prosocyrt on the lower portion of whorls and on base; aperture oval forming a narrow siphonal canal.

Occurrence.-Cerro Roth and Estación Rajapalo, Pliensbachian, Neuquén Province; Cerro Puchenque, Arroyo Serrucho and Arroyo del Portezuelo Ancho, Pliensbachian, Mendoza Province, Argentina. Previously known from Lomas Occidentales and Betancourt, Pliensbachian-Toarcian, Chubut Province, Argentina (Ferrari, 2013).

Description.-Dextral, phaneromphalous, turriculate, highspired and medium- to large-sized shell. The teleoconch has a mean height of $39.9 \mathrm{~mm}$ and mean width of $12.4 \mathrm{~mm}$. The mean apical angle is of $37^{\circ}$, although earliest teleoconch whorls are missing in the better preserved specimens. In the most complete specimens, the teleoconch is composed of eight whorls. The earliest whorls are slightly step-like with a convex swollen belt in the adapical sutural area; the whorls become flat to slightly concave toward mature growth stages. Suture is incised and clearly visible on juvenile whorls. Ornament is poorly developed on juvenile whorls, and stabilizes toward mature teleoconch with an adapical spiral keel on each whorl. Opisthocline collabral lines are visible on the middle of mature whorls and become prosocyrt on the lower portion of whorls and on base. The base is strongly convex and the aperture holostomatous, oval and acute adapically, with the columellar lip strongly expanded abapically forming a narrow siphonal canal.

Materials.-MLP 19638, 25097, 35459, 35469, 35470, 35471, 35472 , 35473, 35474, 35475, 35476, 35477, 35478; MCFPIPH 693, 681, 688, 557, 541; 18 recrystallized specimens.

Dimensions (mm).-Table 1.

Remarks._Pseudomelania feruglioi Ferrari (2013) was previously reported by Ferrari (2013) from the Early Jurassic of the Chubut Province. The specimens from the Chubut Province, however, do not show the step-like earliest whorls with the convex swollen belt in the adapical sutural area, and have instead slightly convex juvenile whorls. Moreover, the Chubut specimens lack the clearly visible opisthocline growth lines in the middle of mature whorls and the prosocyrt lines on base, and lack the columellar lip forming a narrow siphonal canal. These differences are considered here as intraspecific variability within Pseudomelania feruglioi, and have been included in the emended the diagnosis of the species (see above).

Table 1. Dimensions (mm) of Pseudomelania feruglioi Ferrari, 2013. $-=$ missing data; $\mathrm{j}=$ juvenile.

\begin{tabular}{lccc}
\hline Specimen & Height & Width & Apical angle \\
\hline MLP 19638 & 57.6 & 14.2 & $30^{\circ}$ \\
MLP 25097 & 42.0 & 7.0 & - \\
MCF-PIPH 693 & 30.8 & 14.2 & - \\
MCF-PIPH 688/1 & 34.4 & 13.8 & - \\
MCF-PIPH 557 & 38.8 & 15.0 & - \\
MCF-PIPH 541 & 36.0 & 21.0 & - \\
MLP 35469 & 69.3 & 14.2 & $33^{\circ}$ \\
MLP 35472 & 35.6 & 8.8 & $45^{\circ}$ \\
MLP 35473 & 51.5 & 12.3 & - \\
MLP 35459-1 & 30.0 & 10.8 & - \\
MLP 35459-2.j & 13.7 & 5.8 & - \\
\hline
\end{tabular}


The species resembles Pseudomelania procera Eudes-Deslongchamps, 1842 (in d'Orbigny, 1850, p. 41, pl. 239, figs. 2-3), from the Middle Jurassic (Bajocian) of England and France, although the European species is larger and has a narrower apical angle.

For comparisons with similar and coeval Pseudomelania species, see Ferrari (2013, p. 584).

\section{Pseudomelania aff. baugieriana (d'Orbigny, 1850)}

Figure 2.38-2.39

Occurrence.-Carrán Curá, Early Jurassic (Pliensbachian), Neuquén Province, Argentina.

Description.-Dextral and turriculate shell. The fragmentary teleoconch is an internal mould and consists of two whorls; the ramp of whorls is narrow. The outer face becomes flat to slightly convex. The periphery of whorls is bordered by a row of small and rounded nodes. The base is strongly convex and the aperture oval with the outer lip convex and the columellar lip concave.

Materials.-MLP 12174; one recrystallized specimen.

Remarks.-Pseudomelania aff. baugieriana is similar to Pseudomelania baugieriana (d'Orbigny, 1850) (p. 40. pl. 243, fig. 5; Fischer and Weber, 1997, p. 17, pl. 2, fig. 16), from the Early Jurassic (Toarcian) of France; however, the Argentinean material shows a row of weak nodes on the periphery of the shell; the former character is missing in $P$. baugieriana (d'Orbigny). Pseudomelania lorieri (d'Orbigny, 1850) (p. 38, pl. 238, fig. 1; Fischer and Weber, 1997, p. 16, pl. 1, fig. 28), from the Early Jurassic (Toarcian) of France, resembles also the species here described; but, the European form has more convex teleoconch whorls, with the last one less expanded, and lacks the peripheral row of nodes. Pseudomelania repeliniana (d'Orbigny, 1850) (p. 39, pl. 238, fig. 9; Fischer and Weber, 1997, p. 16. pl. 2, figs. 14-15), from the Toarcian of France, has less convex whorls and a more developed axial ornament than the Argentinean species. Pseudomelania $(P$.) disparilis (d'Orbigny, 1850) (p. 47, pl. 243, fig. 6; Fischer and Weber, 1997, p. 21, pl. 2, fig. 9), from the Middle Jurassic (Bajocian) of France, is very similar to $P$. aff. baugieriana, but the European species has less convex whorls and a more developed horizontal ramp.

\section{Family Protorculidae Bandel, 1991 Genus Anulifera Zapfe, 1962}

Type species.-Zygopleura (Anulifera) variabilis Zapfe, 1962, from the Rhaetian (Late Triassic) of Austria.

Occurrence.-Late Triassic-Middle Jurassic. Europe, Asia, South America.

Anulifera chubutensis Ferrari, 2013

Figure 2.40

2013 Anulifera chubutensis Ferrari, p. 585, fig. 3F-G.
Holotype.-SEGEMAR 25000 (cast MPEF-PI 4107), from Lomas Occidentales, Chubut Province, Argentina in the Mulanguiñeu Formation (Ferrari, 2013, fig. 3F).

Occurrence.-Estancia Santa Isabel, Pliensbachian, Neuquén Province. Previously known from Lomas Occidentales, Pliensbachian - Toarcian, Chubut Province, Argentina (Ferrari, 2013).

Description.-See original description in Ferrari (2013, p. 585).

Materials.-MLP 35516; one fragmentary and recrystallized specimen.

Remarks.-The material here analyzed certainly belongs to the species Anulifera chubutensis (see Ferrari 2013, p. 585). Anulifera sigmoidea Ferrari and Damborenea (2015, p. 636, fig. 2.23-31) recently reported from the early Bajocian of the Neuquén province differs from A. chubutensis in being smaller, having a more slender outline shell, a slightly concave mature whorls, and sigmoidal growth lines on the outer face.

For comparisons with other similar species of the genus, see Ferrari (2013).

Superfamily Campaniloidea Douvillé, 1904

Family Ampullinidae Cossmann in Cossmann \& Peyrot, 1919 Genus Globularia Swainson, 1840

Type species.-Ampullaria sigaretina Lamarck, 1804, from the Eocene of France.

Occurrence.-Triassic?/Jurassic-Holocene. Cosmopolitan.

Globularia catanlilensis (Weaver, 1931)

Figure 3.1-3.10

1931 Natica catanlilensis Weaver, p. 378, pl. 42, figs. 277-278.

1934 Natica aff. catanlilensis, Feruglio, 1934, p. 49, pl. 5, figs. 2a, b, 3a, b.

1942 Natica catanlilensis Wahnish, 1942, p. 61, pl. 2, figs. 1a, b.

2013 Globularia cf. catanlilensis (Weaver, 1931); Ferrari, p. 587 , figs. $3 \mathrm{H}, 4 \mathrm{~A}-\mathrm{C}$.

Holotype.-BM 280/1029, from the Early Jurassic of Catán Lil at Southerm Neuquén (Weaver, 1931, p. 378, pl. 42, figs. 277-278). Cast of the holotype: MLP 25017.

Occurrence.-Cerro Roth, Carrán Curá, Estancia Santa Isabel and Catán Lil, Sinemurian-Pliensbachian, Neuquén Province, Argentina; Puesto Araya, Pliensbachian, Mendoza Province, Argentina.

Description.-Dextral, globular, anomphalous, naticiform, low-spired and medium- to large-sized shell. The teleoconch has a mean height of $33.9 \mathrm{~mm}$ and a mean width of $27.7 \mathrm{~mm}$. The apex forms an angle of $109^{\circ}$. The spire is composed of five strongly convex whorls; last whorl is more expanded than the 


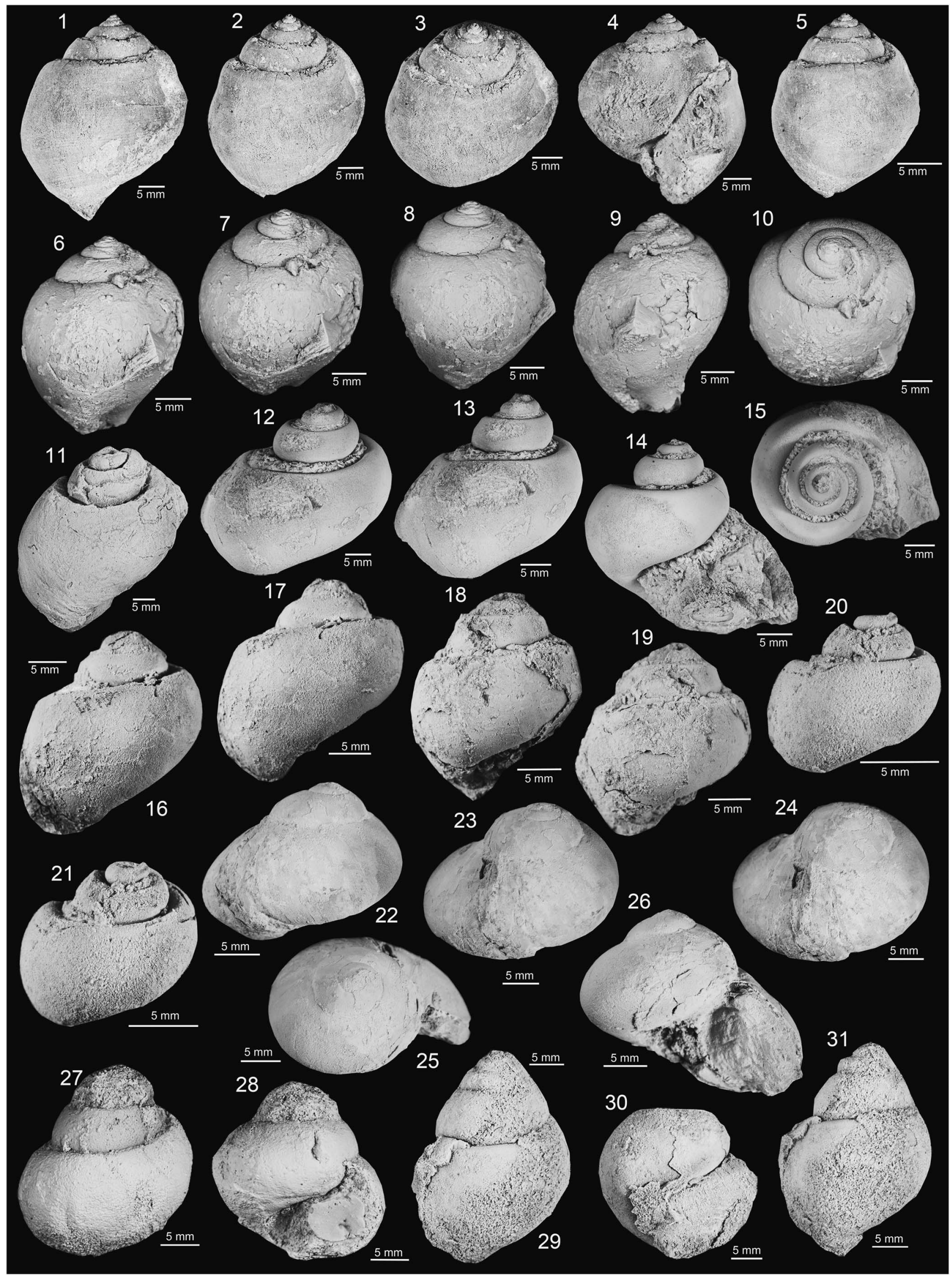


spire representing the $80 \%$ of the shell height. The sub-sutural ramp is narrowly horizontal to slightly convex. The outer face of last whorl is strongly convex in specimen MCF-PIPH 563 and weakly concave in the adapical part of last whorl in specimen MLP 12171. These differences are considered here as intraspecific variability. Sutures are deeply impressed in a concave spiral furrow. The ornament is predominantly spiral and clearly visible on last whorl. The spiral elements consist of very thin and regularly spaced cords; between cords, weak spiral furrows appear. Collabral growth lines are not clearly visible. The base is strongly convex. The umbilicus is closed or partially covered by a columellar callus. The aperture is holostomatous and oval, with the outer lip convex.

Materials.-MLP 12171, 35479, 35480, 35481, 35482, 35515; MCF-PIPH 563; seven recrystallized specimens.

\section{Dimensions (mm).-Table 2.}

Remarks.-Ferrari (2013) suggested that the species originally referred to Natica from the Jurassic of South America should no longer be considered as real representatives of Naticidae and thus were transferred by the author to the genus Globularia. In the present paper, the classification of Ferrari (2013) is followed.

The material here described agree with the diagnostic characters of Globularia, including a globular, naticiform, lowspired, and convex shell, with weak spiral ribs, and the closed umbilical area.

Globularia catanlilensis (Weaver) was original described as Natica catanlilensis Weaver (1931, p. 378, pl. 42, figs. 277-278) from the Early Jurassic of Catan-Lil locality, Neuquén Province, Argentina. Natica klingamanni Weaver (1931; p. 374, pl. 42, figs. 279-280) differs from G. catanlilensis in having a more elongated shell, a narrower spiral angle, a narrower basal angle, a developed collabral ornament with fine growth lines which become sinuous on the outer face of the whorls, and sutures not very distinct. Globularia andina Ferrari and Damborenea (2015, p. 637, fig. 3.1-3.13), from the early Bajocian of the Neuquén Basin, differs from $G$. catanlilensis in having a more gradate

Table 2. Dimensions (mm) of Globularia catanlilensis (Weaver, 1931). $-=$ missing data.

\begin{tabular}{lccc}
\hline Specimen & Height & Width & Apical angle \\
\hline MLP 12171/1 & 36.8 & 28.3 & $104^{\circ}$ \\
MLP 12171/2 & 51.0 & 39.5 & - \\
MLP 35479 & 59.0 & 50.1 & - \\
MLP 35480 & 23.0 & 18.0 & - \\
MLP 35515 & 14.0 & 13.0 & - \\
MLP 35481 & 26.0 & 22.7 & - \\
MLP 35482 & 36.8 & 30.2 & - \\
MCF-PIPH 563 & 25.0 & 20.0 & $115^{\circ}$ \\
\hline
\end{tabular}

shell outline, a more developed horizontal sub-sutural ramp, very fine prosocline growth lines on the outer face of last whorl but lacking spiral cords, and a columellar lip thickened as a callus. Globularia cf. catanlilensis (Weaver) was originally considered by Ferrari (2013) as conespecific to Globularia catanlilensis (Weaver). However, after analyzing in detail the shell characters of both species they share identical morphology and ornament pattern, and Globularia cf. catalilensis is thus retained here as synonymous of G. catanlilensis.

For comparisons with other similar species, see also Ferrari (2013, p. 587).

\section{Genus Naricopsina Chelot, 1886}

Type species.-Lobostoma guarangeri Davoust, 1855, from the Middle Jurassic (Bathonian) of Europe.

Occurrence.-Early Jurassic (Sinemurian)-Upper Cretaceous (Maastrichtian). Europe, Africa, Asia, America.

Remarks.-In the present paper, the genus Naricopsina is considered as a member of Ampullinidae (see Kaim et al., 2004; Ferrari, 2013). According to Gründel (2001b, 2003) the representatives of this genus share a naticiform shell, whose spire is depressed to distinct, with the edge of the aperture not thickened and orthocline, with teleoconch whorls convex, without any sculpture or with weak spiral sculpture. The growth lines are partially thickened, more or less prosocline, straight or sinuous, a narrow but distinct umbilicus is developed, the aperture is broadly oval and the inner lip has a callus that sometimes covers the umbilicus. The species described below fits with the characterization of Gründel (2001b).

\section{Naricopsina aequabilis new species}

Figure 3.11-3.21

Holotype.-MLP 25096; one recrystallized specimen.

Paratype.-MLP 25098; one recrystallized specimen.

Diagnosis.-Globose, step-like shell; narrow, horizontal sub-sutural ramp; outer face convex; last whorl more expanded than the spire; ornament lacking; umbilicus widely opened or covered by a callus; aperture oval.

Occurrence.-Subida a Sañicó, Estancia Santa Isabel and Arroyo Niraico, Pliensbachian-early Toarcian, Neuquén Province; Arroyo Serrucho, Cerro Tricolor, Cañada Colorada, Arroyo El Pedrero, Cerro Puchenque and Puesto Araya, late Sinemurian (F. de Orthechioceras/Paltechioceras) to late Toarcian, Mendoza Province, Argentina.

Figure 3. (1-10) Globularia catanlilensis (Weaver, 1931). (1-5) MLP 12171. (1-2, 5) Lateral views; (3) apical view; (4) lateral and apertural views. (6-10) MCF-PIPH 563. (6-9) Lateral views; (10) apical view. (11-21) Naricopsina aequabilis n. sp. (11) MLP 25098, paratype, lateral view. (12-15) MLP 25096, holotype. (12, 13) Lateral view; (14) apertural view; (15) apical view. (16, 17) MLP 35484, lateral views. (18, 19) MLP 35486, lateral views. $(\mathbf{2 0 , 2 1})$ MLP 27884, lateral views. (22-26) Naricopsina ballentae n. sp., MLP 35494, holotype. (22, 23) lateral views; (24, 25) apical views; (26) lateral and apertural views. (27-31) Pictavia rothi n. sp. (27, 28) MLP 12170. (27) Lateral view; (28) basal and apertural views. (29-31) MLP 12169, paratype. (29, 31) Lateral views; (30) basal and apertural views. 
Description.-Dextral, globose, naticiform, medium-sized and low-spired shell. The protoconch is not preserved. The teleoconch is composed of four strongly convex and step- like whorls. The mean height of the teleoconch is $24.4 \mathrm{~mm}$ and a mean with is $20.5 \mathrm{~mm}$. The apex forms an angle of $103^{\circ}$, although earliest teleoconch whorls are missing in the available specimens. Teleoconch whorls have a narrow and horizontal sub-sutural ramp; the whorls become strongly convex toward the outer face. Suture is deeply incised in a concave spiral furrow. The shell is externally smooth. The base is convex. The umbilicus is widely open or partially covered by a callus. The aperture is holostomatous and broadly oval with the adapical edge acute and the basal edge convex.

Etymology.—Latin, adjective aequabilis = uniform; referring to the uniform ornament pattern and the absence of sinuous collabral ribs on the shell surface, which is a diagnostic character of the genus.

Materials.-MLP 12164, 15552a/b, 27884, 35483, 35484, $35485,35486,35487,35488,35489$, 35490, 35491, 35492, 35493; sixteen recrystallized specimens.

\section{Dimensions (mm).-Table 3.}

Remarks.-The material here described is assigned to Naricopsina on the basis of a naticiform shell shape, lacking a distinct sculpture, the teleoconch whorls strongly convex, the aperture broadly oval, and a callus in the inner lip which sometimes covers the umbilicus (see Gründel, 2001b, 2003; Kaim et al., 2004).

In comparison with other similar Argentinean species, Naricopsina aequabilis n. sp. is very similar to Natica cf. bulimoides (Deshayes), from the Early Cretaceous of the Agrio Formation, Neuquén Province, Argentina (Weaver, 1931, p. 374, pl. 43, figs. 289-290). Both share similar general shell morphology, with a globose shape, spire whorls with a very narrow sub-sutural ramp, aperture oval and the inner lip callused and deflected; however, the species assigned to Natica has a narrower spire angle, is larger than $N$. aequabilis, and the inner lip is separated from the last whorl by a V-shaped depression. Natica cf. philippi Möricke (Jaworski, 1926b, p. 196; Weaver, 1931, p. 377), from the Early Jurassic of Argentina, show resemblance with $N$. aequabilis; however, according to the available descriptions, $N$. cf. philippi has a spire rather higher than $N$. aequabilis, an open umbilicus, and a narrower apical

Table 3. Dimensions (mm) of Naricopsina aequabilis n. sp. - = missing data.

\begin{tabular}{lcccc}
\hline Specimen & Types & Height & Width & Apical angle \\
\hline MLP 25096 & Holotype & 30.0 & 30.7 & $106^{\circ}$ \\
MLP 25098 & Paratype & 44.4 & 39.0 & $109^{\circ}$ \\
MLP 35483 & - & 24.3 & 18.8 & - \\
MLP 35484 & - & 16.8 & 13.5 & $99^{\circ}$ \\
MLP 35485 & - & 20.3 & 18.4 & - \\
MLP 35486 & - & 21.2 & 17.6 & $98^{\circ}$ \\
MLP 35487 & - & 35.5 & 30.0 & - \\
MLP 35488 & - & 32.0 & 24.5 & - \\
MLP 35489 & - & 10.0 & 9.4 & - \\
MLP 35492 & - & 17.0 & 14.2 & - \\
MLP 35493 & - & 29.9 & 19.4 & - \\
MLP 27884 & - & 11.4 & 11.0 & $101^{\circ}$ \\
\hline
\end{tabular}

angle. Naricopsina laevis (Stoliczka, 1861) (Szabó, 2009, p. 98, fig. 91), from the Early Jurassic (Sinemurian) of Europe, resembles $N$. aequabilis, but, the European species is smaller, and has unequally thin and strongly prosocline growth lines. Naricopsina guerangeri (Davoust, 1885) (Gründel, 2001b, p. 62, pl. 5, figs. 3-7), from the Middle Jurassic of Europe, is comparable to the Argentinean species; however, $N$. guerangeri has a lower spire and is smaller than $N$. aequabilis, has orthocline to slightly sinuous and distinctly prosocline growth lines, with their apical part prosocyrt, and fine spiral elements (about 20) on base. Naricopsina montreuilensis (Hébert and Eudes-Deslongchamps, 1860) (Gründel, 2001b, p. 64, pl. 5, figs. 8-12; Gründel, 2003, p. 186, pl. 14, figs. 8-9, pl. 15, figs. 1-4), from the Middle Jurassic (Callovian) of Europe, differs from $N$. aequiabilis in being smaller and in having spiral elements on the shell surface. Naricopsina? sinuosa (Gründel, 2001b, p. 65, pl. 6, figs. 1-6; Gründel, 2003, p. 186, pl. 15, figs. 6-9), from the Middle Jurassic (Callovian) of Europe, resembles the species here described, even though the European form is much smaller than the Argentinean species, and has fine and slightly opisthocyrt growth lines near the adapical suture and on the base. The material described by Szabó and Jaitly (2004, p. 19, pl. 2, figs. 37-39) as Naricopsina cornelia (Laube, 1867), from the Callovian (Middle Jurassic) of India, is also comparable to $N$. aequabilis; the Indian form, however, has a wider apical angle, and irregularly spaced and strongly prosocline growth lines, with weak spiral lines crossing the collabral elements.

\section{Naricopsina ballentae new species}

Figure 3.22-3.26

Holotype.-MLP 35494; one recrystallized specimens.

Paratypes.-MLP 35495, 35496; two recrystallized specimens.

Diagnosis.-Globose, naticiform, very low-spired shell; subsutural ramp lacking; sutures slightly impressed; outer face convex; ornament lacking; last whorl more expanded than the spire and angular toward base; umbilical area widely opened; aperture circular to oval.

Occurrence.-Carrán Curá, late Pliensbachian, Neuquén Province, Argentina.

Description.-Dextral, globose, naticiform, medium-sized and low-spired shell. The apex forms an angle of $115^{\circ}$. The protoconch is not preserved. The teleoconch has a mean height of $14.4 \mathrm{~mm}$ and a mean width of $18.0 \mathrm{~mm}$, and consists of four strongly convex whorls; last whorl markedly more expanded than the spire. Subsutural ramp is missing. Suture is incised in a spiral furrow. The shell is smooth. Last whorl is convex on the outer face and become slightly angular to the periphery. The base is convex with a widely opened umbilical area. The aperture is circular to slightly oval, with the outer lip strongly convex and the columellar lip thickened.

Etymology.-Dedicated to Dr. Sara Ballent (1950-2011), renowned micropalaeontologist from Museo de Ciencias Naturales de La Plata (MLP). 
Dimensions $(\mathrm{mm})$.-MLP 35494, holotype: height $=21.7$; width $=25.0$; apical angle $=115^{\circ}$. MLP 35495, paratype: height $=6.6$; width $=11.5$. MLP 35496, paratype: height $=$ 15.0 ; width $=17.6$.

Remarks.—Naricopsina ballentae n. sp. differs from Naricopsina aequabilis in having a less step-like shall shape, less impressed sutures, and a lower spire.

Naricopsina montreuilensis (Hébert and Eudes-Deslongchamps, 1860) (Gründel, 2001b, p. 64, pl. 5, figs. 8-12; Gründel, 2003, p. 186, pl. 14, figs. 8-9, pl. 15, figs. 1-4), from the Middle Jurassic (Callovian) of Europe, is very similar to $N$. ballentae in shell morphology; however, the European form has a more closed, funnel shaped and narrower umbilical area, a more convex and less angular last teleoconch whorl, fine spiral cords on base and stronger sinuous growth lines. Naricopsina guerangeri (Davoust, 1855) (Gründel, 2001b, p. 62, pl. 5, figs. 3-7), from the Middle Jurassic of Europe, is also comparable to the Argentinean species; however, $N$. guerangeri has a much lower spire, more convex last teleoconch whorl, and a more oval aperture.

\section{Genus Pictavia Cossmann, 1925}

Type species.—Natica pictaviensis d'Orbigny, 1852 (=Natica bajocensis d'Orbigny, 1852) from the Middle Jurassic (Bajocian) of France.

Occurrence.-Early Jurassic-Middle Jurassic; Europe, South America.

Remarks.-Pictavia shows close resemblance with the representatives of the genus Oonia Gemmellaro, 1878. Gründel (2001b), however, pointed out that members of Oonia differs from those of Pictavia in lacking a well-developed sub-sutural ramp on teleoconch whorls, and the growth lines (when present) are sinuous and prosocline. In contrast, members of Pictavia show a narrow ramp which may be smooth or ornamented by spiral rows of fine pits, and the growth lines are straight or only weakly sinuous and distinctly prosocline. Based on these characters, in the present paper the classification of Gründel is followed to include the Argentinean material into Pictavia.

Pictavia rothi new species

Figures 3.27-3.31, 4.1-4.5

Holotype.-MLP 35497; one recrystallized specimen.

Paratypes.—MLP 12169, 15540; two recrystallized specimens.

Diagnosis.-Globose to egg-shaped shell; sub-sutural ramp narrowly horizontal; last whorl more expanded than the spire; ornament lacking; base convex; aperture oval with an S-shaped columellar edge; narrow umbilical area.

Occurrence.-Cerro Roth and Estación Rajapalo, Pliensbachian, and Arroyo Niraico, early Toarcian, Neuquén Province, Argentina.
Description.-Dextral, slightly globose to egg-shaped, smallsized, and moderately high-spired shell. Protoconch is not preserved. Teleoconch is composed of four to five convex whorls with a mean height of $24.4 \mathrm{~mm}$ and a mean width of $13.0 \mathrm{~mm}$. The apex forms an angle of $85^{\circ}$. Last whorl more expanded than spire whorls. Suture is incised in concave spiral furrow and the sub-sutural ramp is narrowly horizontal. The shell is externally smooth and lacks the typical sinuous and prosocline growth lines.

On the last whorl of specimen MLP 12170, near the outer lip, irregularly spaced axial folds are visible. The base is convex and the aperture oval with an S-shaped columellar edge; adapical edge slightly acute and the abapical edge more expanded. A very narrow umbilical area is developed, which sometimes may be covered by a callus.

Etymology.-Dedicated to Dr. Santiago Roth (1850-1924), a renowned Swiss Argentine paleontologist.

Materials.—MLP 12170, 15436; two recrystallized specimens.

Dimensions $(\mathrm{mm})$.-MLP 35497, holotype: height $=24.9$; width $=17.6$; apical angle $=82^{\circ}$. MLP 12169, paratype: height $=29.2 ;$ width $=2.6$; apical angle $=98^{\circ}$. MLP 15540, paratype: height $=23.0$; width $=13.6$; apical angle $=76^{\circ}$. MLP 12170: height $=20.7$; width $=18.3$.

Remarks.-According to Gründel's (2001b) diagnosis, the material here described represents members of Pictavia, considering the narrowly developed sutural ramp as the main diagnostic feature (see above).

The type species Natica pictaviensis d'Orbigny (1852, p. 191, pl. 289, figs. 8-10; Fischer and Weber, 1997, p. 71, pl. 17, figs. 7-8, as Ampullospira [Pictavia] bajociensis), from the Middle Jurassic (Bajocian) of France, is very similar to the Argentinean species; however, the European form has a more slender shell shape, is smaller, has a slightly more developed sub-sutural ramp, and collabral elements.

The analyzed material is also similar to Pictavia calypso (d'Orbigny) (Gründel, 2001b, p. 57, pl. 3, fig. 14, pl. 4, figs. 1-9; 2003, p. 184, pl. 13, figs. 9-10, pl. 14, fig. 1), from the Middle Jurassic (Callovian) of Europe; however, the former species is smaller, and has well developed growth lines on the shell surface, which are intercepted by fine spiral cords. Pictavia punctura (Bean) (Gründel, 2001b, p. 58, pl. 4, figs. 10-15; 2003, p. 185, pl. 14, figs. 2-4), from the Middle Jurassic (Bathonian-Callovian) of Europe, differs from Pictavia rothi $\mathrm{n}$. sp. in having a more developed collabral ornament with fine prosocline to slightly opisthocyrt growth lines, which are more developed on last teleoconch whorl.

\section{Genus Oonia Gemmellaro, 1878}

Type species.-Melania abbreviata Terquem $1855=$ Pseudomelania hettangiensis Cossmann 1909, from the Early Jurassic of France. 
Occurrence.-Early Jurassic-Middle Jurassic; Europe, South America.

Remarks.-As it is pointed out above, Oonia shows extreme resemblance with representatives of Pictavia. The difference between both genera relies in that Oonia lacks a sub-sutural ramp on the outer face of whorls and the growth lines are distinctly sinuous (weakly sinuous in Pictavia) and prosocline. The classification of Gründel (2001b) is also followed here.

\section{Oonia acuta new species}

Figure 4.6-4.14

?1926 Oonia euspiroides (Gemmellaro, 1878); Jaworski, 1926, p. 200.

?1931 Oonia cf. euspiroides (Gemmellaro, 1878); Weaver 1931 , p. 371.

2001a cf. Oonia Gründel, p. 59, pl. 5, fig 1-4.

Holotype.-MLP 12159/a; one recrystallized specimen.

Paratypes.-MLP 12159/b, 35498, 35499; five recrystallized specimens and one negative mould.

Diagnosis._Globose, acute, high-spired shell; juvenile whorls slightly convex; mature whorls strongly convex; last whorls markedly expanded and elongated; spiral ornament predominant on juvenile whorls, opisthocyrt collabral ribs on mature whorls; base convex, aperture elongated and oval; umbilical area covered by a thin columellar callus.

Occurrence.-Cerro Roth, Pliensbachian, Neuquén Province; Paso del Portezuelo Ancho, Arroyo Malo and Arroyo Serrucho, late Hettangian to Pliensbachian, Mendoza Province, Argentina. Portezuelo de Pederales and Quebrada Cachina, Early Jurassic (Hettangian-Pliensbachian), Chile (Gründel, 2001a).

Description.-Dextral, globose, medium-sized and moderately high-spired shell, with a strongly oval and acute shape. The protoconch is not preserved. The teleoconch has a mean height of $26.3 \mathrm{~mm}$ and a mean width of $15.2 \mathrm{~mm}$, and is composed of seven convex whorls. The teleoconch is higher than wide with an apical angle of $65^{\circ}$. The three earliest teleoconch whorls are flat to slightly convex, becoming strongly convex toward the mature growth stages. Last teleoconch whorl is more expanded than spire and elongated toward the abapical edge. Suture is deeply incised in a spiral furrow. The three to four juvenile whorls have a predominant spiral ornament, consisting on weak and fine irregularly spaced cords. On mature whorls, spiral cords become obsolete and opisthocyrtic collabral ribs are visible. The base is convex and the aperture strongly elongated and oval. The columellar lip forms a thin callus and the umbilical canal is
Table 4. Dimensions (mm) of Oonia acuta n. sp. $-=$ missing data.

\begin{tabular}{llccc}
\hline Specimen & Types & Height & Width & Apical angle \\
\hline MLP 12159/a & Holotype & 20.0 & 10.5 & $81^{\circ}$ \\
MLP 12159/b & Paratype & 23.6 & 11.8 & $83^{\circ}$ \\
MLP 35498 & Paratype & 19.3 & 15.6 & $61^{\circ}$ \\
MLP 35499 & Paratype & 19.1 & 13.2 & $65^{\circ}$ \\
MB.Ga.787 & - & 27.4 & 15.4 & $61^{\circ}$ \\
MB.Ga.786 & - & 35.1 & 20.5 & $57^{\circ}$ \\
MB.Ga.789 & - & 39.9 & 19.7 & $46^{\circ}$ \\
\hline
\end{tabular}

deeply impressed. A small siphonal notch is visible on the basal lip in specimen MLP (33).

Etymology.-Latin, adjective acuta $=$ acute; referred to the strongly acute shell.

Materials.-MB.Ga.786, 787, 789; three recrystallized specimens. Specimens originally assigned by Gründel (2001a) to cf. Oonia sp., from the Early Jurassic (HettangianPliensbachian) of Chile.

\section{Dimensions (mm).-Table 4.}

Remarks.-Oonia acutovata Gründel (2001b, p. 60, pl. 4, figs. 16-17, pl. 5, figs. 1-2), from the Middle Jurassic (Bathonian-Callovian) of Europe, differs from O. acuta n. sp. in having a more oval shell and the inner lip forming a narrow callus, and in being smaller.

The genus Oonia was previously reported from Argentina by Jaworski (1926) and Weaver (1931). Oonia euspiroides (Gemmellaro, 1878) (Jaworski, 1926, p. 200; Weaver, 1931, p. 371 as $O$. cf. euspiroides), from the Early Jurassic of Portezuelo Ancho (Mendoza, Argentina), shows close resemblance to O. acuta; however, neither Jaworski nor Weaver figured their material. According Gemmellaro's (1878) diagnosis, O. euspiroides has well developed growth lines on the shell surface and a narrower spire angle. Considering that $O$. acuta comes from the same locality (Paso del Portezuelo Ancho) that Oonia euspiroides, here the species described by Jaworski (1926) and Weaver (1931) are doubtfully included as synonymous of the new species.

\section{Subclass Heterobranchia Gray, 1840}

Order Architectibranchia Haszprunar, 1985 (= Order Opisthobranchia Milne Edwards, 1848)

Remarks.-Gründel and Nützel (2012) pointed out that shells bearing heterobranchs such as modern Acteon or Bullina have been traditionally considered to represent basal opisthobranchs. The authors revised and discussed some Triassic and Jurassic opisthobranch genera, which are related to the modern forms, and based on recent molecular studies they supported the idea that

Figure 4. (1-5) Pictavia rothi n. sp. (1, 2) MLP 15540, paratype, lateral views. (3-5) MLP 35497, holotype, lateral views. (6-14) Oonia acuta n. sp. (6-9) MLP 12159/a, holotype. (6, 7) Lateral views; $(\mathbf{8 , 9}$ ) lateral and apertural views. (10) 12159/b, paratype, lateral view. (11, 12) MLP 35499, lateral views. (13, 14) MLP 35498, lateral views. (15-20) Striactaeonina transatlantica (Behrendsen). (15, 16) MLP 25094a/b, lateral views. (17) MLP 35508, lateral view. (18) MLP 35510, lateral view. (19, 20) MLP 35509, lateral and apertural views. (21-27) Cylindrobullina ovata (Behrendsen, 1891). (21) MLP 35514, lateral view. (22-24) MCF-PIPH 546. (22) Lateral view; (23) lateral and apertural views; (24) apical view. (25, 26) MLP 35511, lateral views; (27) MLP 35512, lateral view. (28, 29) Cylindrobullina brevispira n. sp., MLP 35513, holotype. (28) Lateral view; (29) apical view. 


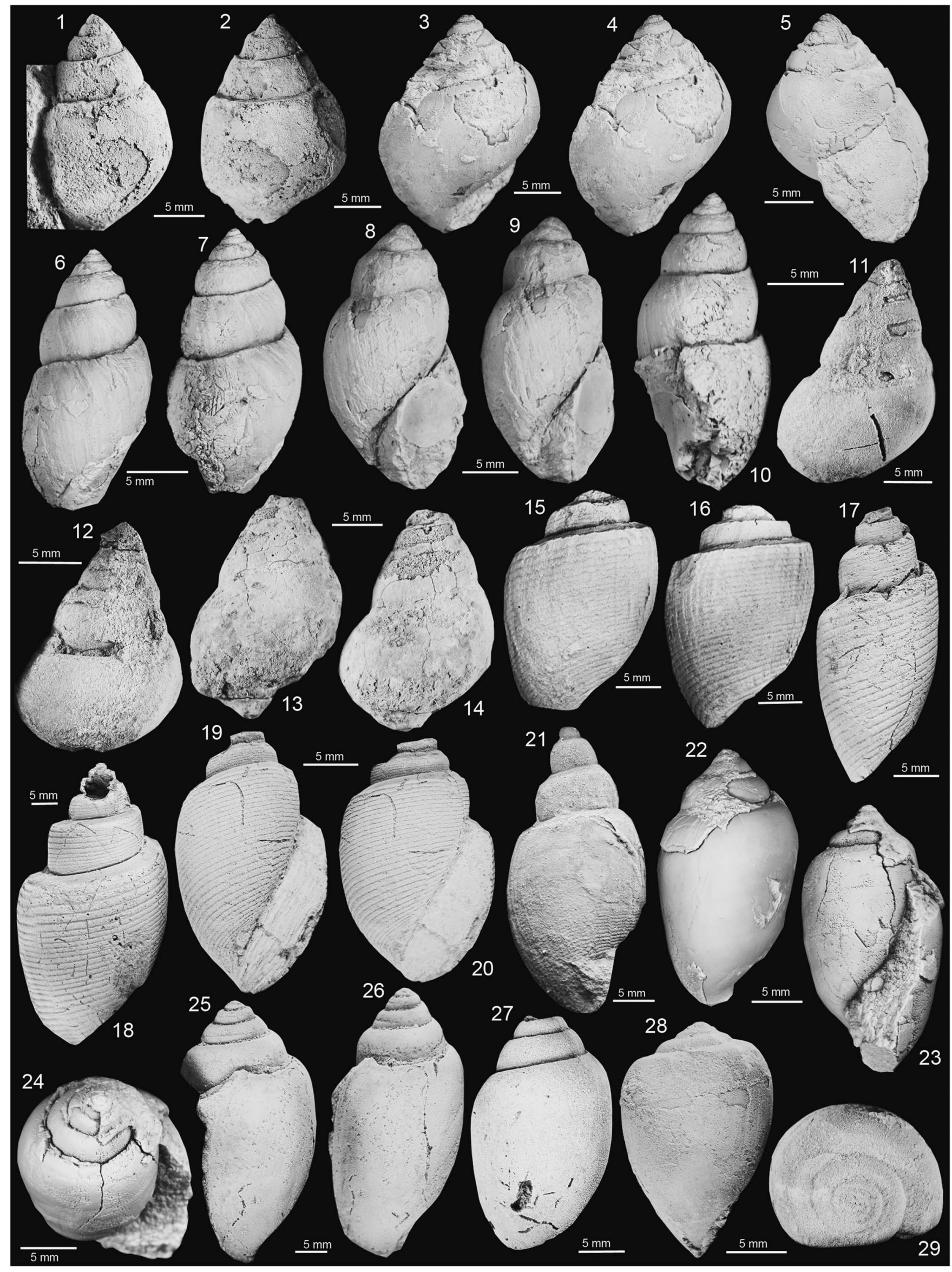


Opisthobranchia is not a monophyletic group (Dinapoli and Klussmann-Kolb, 2010; Schrödl et al., 2011). Thus, they used the name Architectibranchia to include Mesozoic representatives of Opisthobranchia. In the present paper, the classification of Gründel and Nützel (2012) is followed.

Superfamily Acteonoidea d'Orbigny, 1843

Family Tubiferidae Cossmann, 1895

Genus Striactaeonina Cossmann, 1895

Type species.-Orthostoma avena Terquem, 1855; Early Jurassic (Hettangian) of Luxembourg.

Occurrence.-Early Jurassic-Middle Jurassic; Europe, South America.

Remarks.-Based on the characterization of Gründel and Nützel (2012) memebers of Striactaeonina share 'cylindrical to oval shells, with distinctly elevated spire. The last whorl is moderately convex and not inflated. The whorls have a sub-sutural ramp, which is oblique in most cases. The ramp is demarcated from whorl face by a spiral furrow. Spiral striae are present in whorls flanks and on base. The growth lines are prosocyrt and curving backward in their adapical portion. The aperture is drop- shaped, with the outer lip convex and the inner lip showing a convex parietal and concave columellar portion. Considering these diagnostic characters, the specimens described below are retained into Striactaeonina.

Striactaeonina transatlantica (Behrendsen, 1891) Figure 4.15-4.20

1891 Actaeonina transatlantica Behrendsen, p. 383, pl. 22, fig. 9.

1894 Actaeonina transatlantica Behrendsen, Möricke, p. 31.

1922 Actaeonina transatraltica Behrendsen; Behrendsen, p. 169 , pl. 1, fig. 7.

1926a Striactaeonina transatlantica (Behrendsen); Jaworski, p. 400.

1926b Striactaeonina transatlantica (Behrendsen); Jaworski, p. 201.

1931 Striactaeonina transatlantica (Behrendsen); Weaver, p. 390.

1982 Striactaeonina transatlantica (Behrendsen); Pérez, p. 123 , pl. 16, fig. 16 .

2001 Striactaeonina transatlantica (Behrendsen); Gründel, p. 65, pl. 6, figs. 10-11.

Type material.-Several specimens, originally described by Behrendsen (1891) from the Early Jurassic of Paso del Portezulo Ancho, Mendoza Province, Argentina (Behrendsen, 1891, p. 383, pl. 22, fig. 9). Behrendsen's original material, which should be housed at Göttingen, Germany, could not be examined, and thus no lectotype designation is proposed here.

Occurrence.-Cerro Roth, Pliensbachian, Neuquén Province; Arroyo Serrucho, Cerro Puchenque, Paso del Portezuelo Ancho
Table 5. Dimensions (mm) of Striactaeonina transatlantica (Behrendsen, 1891). $-=$ missing data.

\begin{tabular}{lccc}
\hline Specimen & Height & Width & Apical angle \\
\hline MLP 25094/a & 23.9 & 16.7 & $90^{\circ}$ \\
MLP 25094/b & 27.2 & 17.0 & $96^{\circ}$ \\
MCF-PIPH 547 & 13.5 & 10.3 & - \\
MLP 35500 & 33.0 & 20.7 & - \\
MLP 35501 & 36.8 & 20.5 & - \\
MLP 35502 & 23.9 & 16.5 & - \\
MLP 35503 & 23.5 & 18.9 & - \\
MLP 35504 & 35.4 & 26.7 & - \\
MLP 35505 & 31.5 & 19.7 & - \\
MLP 35506 & 48.4 & 26.2 & $68^{\circ}$ \\
MLP 35508 & 32.7 & 14.5 & $83^{\circ}$ \\
MLP 35509 & 24.3 & 14.2 & $69^{\circ}$ \\
MLP 35510 & 51.6 & 27.7 &
\end{tabular}

and Arroyo del Portezuelo Ancho, Pliensbachian, Mendoza Province, Argentina.

Description.-Dextral, anomphalous, medium-sized and low-spired shell, with an oval to cylindrical shape. The protoconch is not preserved. The teleoconch has a mean height of $31.2 \mathrm{~mm}$ and a mean width of $19.2 \mathrm{~mm}$, is strongly stepped in outline and consists of approximately three to four flat to slightly convex whorls. The apex forms an angle of $81^{\circ}$, although earliest whorls are missing in the available specimens. Last teleoconch whorl is more expanded than the spire. Suture is incised and bordered by a weak spiral furrow. The sub-sutural ramp is smooth, horizontal and narrow, and bordered by a peripheral and acute spiral cord. The outer face is flat and becomes slightly convex toward the last whorl and is ornamented by regularly spaced spiral cords; the interspaces between cords develop weak spiral furrows. Collabral ornament is lacking. The base is convex to slightly angular, and the aperture oval.

Materials.-MLP 25094a/b, 25095, 35500, 35501, 35502, 35503, 35504, 35505, 35506, 35507, 35508, 35509, 35510; MCF-PIPH 547; 15 recrystallized specimens.

Dimensions ( $\mathrm{mm})$.- - Table 5.

Remarks.-Striactaeonina transatlantica was previously reported in the Early Jurassic of Argentina by several authors (Behrendsen, 1891, 1922; Möricke, 1894; Jaworski, 1926a, b; Weaver, 1931). Particularly, this species occurs in Pliensbachian deposits of Portezuelo Ancho (Mendoza Province) and Catán Lil (Neuquén Province); but also is present in coeval marine sediments at Qda. Asientos and Jorquera/La Guardia (Chile) (see Pérez, 1982; Gründel, 2001a). Striactaeonina atuelensis Gründel, 2001a (p. 66, pl. 6, figs. 7-8), from the Early Jurassic (early Pliensbachian) of Río Atuel (Mendoza) has recently been revised at the Museum für Naturkunde repository (specimen MB.Ga.803). The species from Chile is very similar to $S$. transatlantica in general shell morphology and ornament pattern; however, it is slightly smaller than $S$. transatlantica, has a spire with slightly more convex whorls and a less gradate outline shell, has a narrower sub-sutural ramp, and a wider apical angle of $111^{\circ}$. Actaeonina (Striactaeonina) supraliasica Cox (1965, p. 173, pl. 29, fig. 4a, b, c), from the Early Jurassic (Toarcian) of 
Kenya, is slightly smaller than the Argentinean form, has a more acute spire and narrower sub-sutural ramp.

\section{Family Cylindrobullinidae Wenz, 1938}

Remarks.-Gründel and Nützel (2012) argued that Cylindrobullina represents the oldest confirned genus of the family Cylindrobullinidae with it first certain occurrence from the Late Triassic of South America (Haas, 1953). Gründel (2010) redescribed the type species of the genus, Cylindrobullina fragilis (Dunker, 1846), and suggested that the use of the genus had to be changed. Representatives of Cylindrobullina have cylindrical shells with a somewhat elevated spire.

\section{Genus Cylindrobullina von Ammon, 1878}

Type species.-Cylindrobullina fragilis (Dunker, 1846), from the Early Jurassic (Hettangian) of North Germany.

Occurrence.-Late Triassic-Late Jurassic; Europe, South America.

Remarks.-The genus Cylindrobullina shows extreme resemblance with Actaeonia and thus, the assignment of some species to one or the other is usually questionable. Gründel and Nützel (1998) considered Cylindrobullina and Actaeonina as synonymous, giving the priority to Actaeonina. Later, Gründel and Nützel (2012) stated out that the systematic placement of Actaeonina is unclear due to the unknown protoconch of the type species, A. carbonaria (de Koninck, 1843). The authors suggested that the teleoconch morphology of A. carbonaria resembles that of the Mesozoic species of 'Cylindrites', including a low spire, very narrow aperture, and a distinct ramp which is demarcated by an angulation from the whorls flank. These similarities suggest that Actaeonina could be indeed the earliest member of Cylindrobullina/Cylindrites group. Representatives of Cylindrobullina share a cylindrical shell shape, the whorls embrace just below the subsutural ramp, the aperture is high and narrow, the spire is low and distinct, whorls are smooth or weakly ornamented with strengthened growth lines, spiral striae or spiral threads on base, growth lines on the flanks weakly prosocyrt and on the ramp directed backward and opisthocyrt, aperture very high, and the protoconch (although unknown from the type species) is heterostrophic (see diagnosis of Gründel, 2010; Gründel and Nützel, 2012). These characters are considered here to assign the specimens described below to Cylindrobullina.

\section{Cylindrobullina ovata (Behrendsen, 1891) new combination \\ Figure 4.21-4.27}

1891 Actaeonina ovata Behrendsen, p. 383, pl. 22, fig. 7.

2015 Actaeonina ovata Behrendsen, 1891; Ferrari, p. 88, fig. 7 $\mathrm{R}-\mathrm{T}$.

Type material.-One specimen originally described by Behrendsen (1891) from the Early Jurassic of Paso del Portezuelo Ancho, Mendoza Province, Argentina (Behrendsen, 1891, p. 383, pl. 22, fig. 7). Behrendsen's original specimen, which should be housed at Göttingen, Germany, could not be examined.

Emended diagnosis.-Oval, egg-shaped shell; teleoconch whorls convex; last whorl greatly expanded; sub-sutural ramp horizontal; prosocyrt collabral ribs; regularly spaced spiral furrows on base.

Occurrence.-Cerro Roth, Pliensbachian, Neuquén Province; Cerro Puchenque, Paso del Portezuelo Ancho and Arroyo Serrucho, Pliensbachian, Mendoza Province, Argentina.

Description-—Dextral, oval, egg-shaped, medium-sized and low-spired shell. The protoconch is not preserved. The teleoconch is composed of five convex whorls with a mean height of $23.9 \mathrm{~mm}$ and a mean width of $13.8 \mathrm{~mm}$. The axis forms an apical angle of $72^{\circ}$. Last teleoconch whorl is greatly more expanded than the spire. The spire is low. The sub-sutural ramp is narrowly horizontal and convex. The outer face of whorls is strongly convex. Suture is impressed in a weak spiral furrow. The shell is smooth, or has prosocyrt collabral ribs on last teleoconch whorl in some specimens. The base is convex with fine and regularly spaced spiral furrows. The aperture elongated and strongly oval, with the posterior end acute and the anterior end expanded. The columellar lip is thin.

Materials.-MCF-PIPH 546, MLP 35511, 35512, 35514; four recrystallized specimens.

Dimensions $(\mathrm{mm})$. - MLP 35514: height $=17.2$; width $=8.7$; apical angle $=54^{\circ}$. MCF-PIPH 546: height $=22$; width $=13$; apical angle $=87^{\circ}$. MLP 35511: height $=29.2$; width $=15.8$; apical angle $=75^{\circ}$. MLP 35512: height $=27.2$; width $=17.8$; apical angle $=72^{\circ}$.

Remarks.-The species was originally described by Behrendsen (1891, p. 383, pl. 22, fig. 7) under the genus Actaeonina, from the Early Jurassic of Portezuelo Ancho (Mendoza Province, Argentina). Here, Behrendsen's species is reassigned to Cylindobullina, following the updated characterizations of Gründel (2010) and Gründel and Nützel (2012). Moreover, the new material here described show the typical prosocyrt growth lines on the shell surface and the spiral striae on base. The spiral ornament was not described in the original characterization of Behrendsen, and in the present paper this character is included in the emended the diagnosis of the species.

Cylindrobullina ovata resembles Actaeonina novozealandica Bandel et al. (2000, p. 101, pl. 10, figs. 8-10, 12), from the Early Jurassic of New Zealand; however, the species described by Bandel et al. (2000) is much smaller than C. ovata, has a higher spire shell, a teleoconch whorls with rounded angular corner, a developed spiral groove, and fine growth lines on the shell surface. Actaeonina submoorei Kuhn (1936) (in Gründel and Nützel, 1998, p. 76, pl. 4, figs. 5-10), from the Early Jurassic (Pliensbachian) of Germany differs from $C$. ovata in having a more developed sub- sutural ramp, spiral grooves on the angular corner of whorls, and a more acute spire. Actaeonina domeria Gründel and Nützel (1998, p.77, pl. 5, figs. 2-4), Actaeonia 
obliquata Gründel and Nützel (1998, p.78, pl. 4, fig. 11-12, pl. 5, fig. 1) and Actaeonina rara Gründel and Nützel (1998, p.78, pl. 4, figs. 11-12, pl. 5, fig. 1), all from the Early Jurassic (early Pliensbachian) of Germany, have wider sub- sutural ramps in comparison to A. ovata. Cylindrobullina arduennensis (Piette, 1856) (in Gründel and Nützel, 2012, p. 36, fig. 2), from the Early Jurassic (Hettangian) of France, is very similar to C. ovata in shell shape, although the European form is much smaller.

Haas (1953) described many Cylindrobullina species from the Late Triassic of the Pucará Group (Central Peru), which are very similar to $C$. ovata. Cylindrobullina (Cylindrobullina?) pyrulaeformis Haas (1953, p. 266, pl. 17, figs. 67-69, 72-72, 84, 85) and Cylindrobullina (C?) obesa Haas (1953, p. 264, pl. 17, figs. 54-57, 60-63, 65, 66, 70, 71, 75, 76, 79-82, 86) differs from $C$. ovata in having strongly convex whorls, and more pronounced sutural ramps. Particularly, Cylindrobullina (C.?) pyrulaeformis has a strongly corkscrew- shaped columella and Cylindrobullina (C.?) obesa has a slightly concave base; these characters are not visible in $A$. ovata.

\section{Cylindrobullina brevispira new species}

Figure 4.28-4.29

Holotype.-MLP 35513; one recrystallized specimen.

Diagnosis.-Egg-shaped; extremely low spire for the genus; sub-sutural ramp widely horizontal; last whorls greatly expanded; ornament lacking; aperture elongated and oval.

Occurrence.-Arroyo Serrucho, Pliensbachian, Mendoza Province, Argentina.

Description.-Dextral, oval, egg-shaped, medium-sized and very low-spired shell. The protoconch is not preserved. The teleoconch is composed of five convex whorls and has a height of $25.0 \mathrm{~mm}$ and a width of $17.4 \mathrm{~mm}$. The axis forms an apical angle of $120^{\circ}$. Last teleoconch whorl is greatly more expanded than spire. The sub-sutural ramp is widely horizontal and forms a rounded edge as transition with last whorls; the outer face of whorls is strongly convex. Suture is impressed in a weak spiral furrow. The shell is smooth and the base convex. The aperture is elongated and strongly oval, with the posterior end acute.

Etymology.-Referred to the extremely low-spired shell in comparison with other representatives of the genus.

Dimensions (mm).-MLP 35513, holotype: height $=25$; width $=17.4$; apical angle $=120^{\circ}$.

Remarks.-Cylindrobullina brevispira n. sp. shows a more obtuse apical angle and a more convex whorls outline than Cylindrobullina ovata. Cylindrobullina brevispira is also comparable to the type species Cylindrobullina fragilis (Dunker, 1846), from the Early Jurassic (Hettangian) of North Germany; however, the European form has a more elevated spire and clearly visible opisthocyrt collabral ribs on the outer face of last whorl. Cylindrobullina arduennensis (Piette, 1856) (in Gründel and Nützel, 2012, p. 36, fig. 2), from the Early Jurassic (Hettangian) of France, is similar to $C$. brevispira, although the
European form is much smaller, has a less convex last whorl with opistocyrt collabral ribs, and a slightly more elevated spire.

\section{Acknowledgments}

I am deeply grateful to S. Damborenea (MLP) for providing most of the specimens described here, which were collected by her from 1975 onwards during field trips to the Neuquén Basin accompanied by M. Manceñido and A. Riccardi (both at MLP) to whom I also extend my gratitude. I thank A. Riccardi for allowing access to the MLP collection and for supplying an updated biostratigraphical framework for the Neuquén Basin. I also thank the Dirección General de Patrimonio Cultural, Secretaría de Estado de Cultura de la Provincia de Neuquén, and L. Zingoni, who allowed the access to outcrops in his land in southern Neuquén Province. I am also grateful to R. Coria (Museo Carmen Funes, Plaza Huincul, Neuquén, Argentina) for arranging the loan of the gastropod material collected by the author. I extend my gratitude to S. Bessone (CENPAT), L. Canessa (MEF), and N. Pfeiffer (MEF) for preparation of specimens; and to M. Manceñido and J. Echevarría (MLP) for their help during fieldwork in the Neuquén Basin in 2012. I thank S. Lanés for providing specimens from Arroyo El Pedrero and J. Groizard (ALUAR) for allowing access to the scanning electron microscope. Study of the MLP and MCF-PIPH gastropod material was made possible by a Sylvester-Bradley Award from the Palaeontological Association. The revision of the MB.Ga. gastropod material was made posible in part by a project financed by AGENCIA being PICT 2013-0356. I thank M. Aberhan (Museum für Naturkunde, Berlin) for allowing the access to the MB.Ga. invertebrate collection. This study is also part of a longterm project financed by CONICET grants, the last one being PIP 112-200801-01567. Finally, I extend my gratitude to R. Gatto (Dipartimento di Geoscienze, Università di Padova, Italy) and A. Beu (GNS, New Zealand) for their valuable comments, which helped to greatly improve the manuscript.

\section{References}

Bandel, K., 1991, Über triassische "Loxonematoidea" und ihre Beziehungen zu rezenten und paläozoischen Schnecken: Paläontologische Zeitschrift, v. 65, p. 239-268.

Bandel, K., Gründel, J., and Maxwell, P., 2000, Gastropods from the upper Early Jurassic/early Middle Jurassic of Kaiwara Valley, North Canterbury, New Zealand: Freiberger Forschungshefte, C 490, p. 67-132.

Behrendsen, O., 1891, Zur Geologie des Ostabhanges der argentinischen Cordillere. Teil I: Zeitschrift der Deutschen Geologischen Gesellschaft, 43, p. $369-420$.

Behrendsen, O., 1922, Contribución a la geología de la pendiente oriental de la Cordillera Argentina: Actas de la Academia Nacional de Ciencias (Córdoba), v. 7, p. 161-227.

Chelot, E., 1886, Supplément à la géologie de la Sarthe de A. Guillier: Bulletin de la Société géologique de France, v. 15, 9 p.

Cossmann, M., 1895-1924, Essais de Paléoconchologie Comparée: Different publishers, Paris, $3144 \mathrm{p}$.

Cossmann, M., 1902, Rectifications de nomenclature: Revue critique de Paléozoologie, v. 6, 223 p.

Cossmann, M., 1906, Essais de Paléoconchologie Comparée. Septième Livraison: Paris, M. Cossmann, F.R. de Rudeval, 261 p.

Cossmann, M., 1909, Essais de Paléoconchologie Comparée: Huitième Livraison: Paris, M. Cossmann, F.R. de Rudeval, 248 p.

Cossmann, M., 1925, Essais de Paléonconchologie comparée, v. 13, 345 p.

Cossmann, M., and Peyrot, A., 1919, Conchologie néogénique de l'Aquitaine, tome III: Actes de la Société Linnéenne de Bordeaux, v. 70, p. $181-356$. 
Cox, L.R., 1959, Thoughts on the classification of the Gastopoda: Proceedings of the Malacological Society of London, v. 33, 239-261.

Damborenea, S.E., 1987, Early Jurassic Bivalvia of Argentina. Part I: Stratigraphical Introduction and Superfamilies Nuculanacea, Arcacea, Mytilacea and Pinnacea: Palaeontographica A, v. 99, p. 23-111.

Damborenea, S.E., and Ferrari, S.M., 2008, El género Lithotrochus Conrad (Gastropoda, Vetigastropoda) en el Jurásico temprano de Argentina: Ameghiniana, v. 45, p. 197-209.

Davoust, A., 1855, Recherches faites par M. L. Abbé Davoust, sur la dixième question du deuxième paragraphe: Bulletin de la Société d'Agriculture, Sciences et Arts de la Sarthe, v. 3, p. 463-517.

de Koninck, L., 1842-1851, Description des animaux fossiles qui se trouvent dans le terrain carbonifère de Belgique: Liège, $716 \mathrm{p}$.

de Lamarck, J.B., 1804, Mémoires sur les fossiles des environs de Paris (Suite 4): Annales du Muséum National d'Histoire Naturelle, v. 5, p. 28-36.

Delpey, G., 1937, Symbiose d'un Nerinée et d'un Hydrozoaire: Bulletin de la Société géologique de France, v. 7, 353-358.

Delpey, G., 1940, Les gastéropodes mésozoïques de la region Libanaise: Notes et Mémoires de la Section d' Études Géologiques du Haut-Commissairiat de la République France en Syrie et au Liban, Service des Travaux Publics, v. 3, p. 5-114.

Deshayes, G.P., 1830-1832, Encyclopédie méthodique ou par ordre de matières: Histoire naturelle des Vers et Mollusques, v. 1-2, p. 1-256.

d'Orbigny, A., 1842-1843, Paléontologie Francaise. Terrains Crétacés. II: Gastropodes: Paris, FR. Victor Masson, Paris, 456 p.

d'Orbigny, A., 1850-1860, Paléontologie Française, Terrain Jurassique II, Gastéropodes: Paris, FR. Victor Manson, 622 p.

Douvillé, H., 1904, Mollusques Fossiles, in J. de Morgan, ed., Mission scientifique en Perse: Paris, Leroux, p. 25-50.

Dunker, W., 1846, Diagnosen einiger neuer Conchylien aus der norddeutschen Liasbildung: Zeitschrift für Malakozoologie, v. 3, p. 168-171.

Feruglio, E., 1934, Fossili Liassici della Valle del Rio Genua (Patagonia): Giornale di Geologia, Annali del R. Museo Geologico di Bologna, v. 9, p. 1-64.

Ferrari, S.M., 2009, Cosmopolitan Early Jurassic marine gastropods from westcentral Patagonia, Argentina: Acta Palaeontologica Polonica, v. 54, p. 449461.

Ferrari, S.M., 2011, Early Jurassic Ataphridae (Mollusca: Gastropoda) from Chubut, Argentina: paleogeographic and paleoecologic implications: Ameghiniana, v. 48, p. 63-77.

Ferrari, S.M., 2012, The genera Cryptaulax and Procerithium (Procerithiidae, Caenogastropoda) in the Early Jurassic of Patagonia, Argentina: Alcheringa, v. 36, p. 323-336.

Ferrari, S.M., 2013, New Early Jurassic gastropods from west-central Patagonia, Argentina: Acta Palaeontologica Polonica, v. 58, p. 579-593.

Ferrari, S.M., Kaim, A., and Damborenea, S.E. 2014, The genera Calliotropis Seguenza and Ambercyclus n. gen: (Vetigastropoda, Eucyclidae) from the Early Jurassic of Argentina: Journal of Paleontology, v. 88, p. $1174-1188$.

Ferrari, S.M., 2014, Patellogastropod and Vetigastopoda (Mollusca, Gastropoda) from the marine Jurassic of Patagonia, Argentina: Historical Biology, v. 26, p. $563-581$

Ferrari, S.M., Kaim, A., and Damborenea, S.E. 2014, The genera Calliotropis Seguenza and Ambercyclus n. gen.: (Vetigastropoda, Eucyclidae) from the Early Jurassic of Argentina: Journal of Paleontology, v. 88, p. 1174-1188.

Ferrari, S.M., 2015, Early Jurassic marine gastropods from Argentina: a palaeobiogeographical analysis based on Vetigastropoda: Journal of Systematic Palaeontology, v. 13, p. 919-941.

Ferrari, S.M., and Bessone, S., 2015, A new Early Jurassic marine locality from southwestern Chubut Basin, Argentina: Andean Geology, v. 42, p. 349-363.

Ferrari, S.M., and Damborenea, S.E., 2015, Early Bajocian marine gastropods from the Neuquén Basin, Argentina: Ameghiniana, v. 52, p. 625-646.

Ferrari, S.M., Damborenea, S.E., Manceñido, M.O., and Griffin, M., 2015, Early Jurassic Trochotomidae (Vetigastopoda, Pleurotomarioidea) from the Neuquén Basin, Argentina: Journal of Paleontology, v. 89, p. 331-345.

Fischer, J-C., and Weber, C., 1997, Revision critique de la Paleontologie Française d'Alcide d'Orbigny, vol II, Gastropodes jurassiques: Paris, Masson, $300 \mathrm{p}$.

Gemmellaro, G.G., 1878, Sui fossili del calcare cristallino delle montagne del Casale e di Bellampo nella Provincia di Palermo: Giornale di Scienze Naturali ed Economiche, Palermo, v. 13, p. 116-212.

Golikov, A. N., and Starobogatov, Y. I., 1975, Systematics of prosobranch gastropods: Malacologia, v. 15, p. 185-232.

Gray, J.E., 1840, Shells of Mollusc animals. in., Synopsis of the contents of the British Museum, p. 106-156.

Gray, J.E., 1853, On the division of ctenobranchous gasteropodous Mollusca into larger groups and families: Annals and Magazine of Natural History, v. 11, p. 124-132.
Gründel, J., 1999, Procerithiidae (Gastropoda) aus dem Lias und Dogger Deutschlands und Polens: Freiberger Forschungshefte, C 481, p. 1-37.

Gründel, J., 2001a, Gastropoden aus dem Jura der südamerikanischen Anden: Freiberger Forschungshefte, C492, p. 43-84

Gründel, J., 2001b, Neritimorpha und weitere Caenogastropoda (Gastropoda) aus dem Dogger Norddeutschlands und des nordwestlichen Polens: Berliner Geowissenschaftliche Abhandlungen, Reihe, E 36, p. 45-99.

Gründel, J., 2003, Die gastropoden der Dogger-Geschiebe Deutschlands und des nordwestlichen Polens: Archiv für Geschiebekunde, 4, p. 129-132.

Gründel, J., 2010, Neubeschreibung der Gastropodenfauna aus dem Hettangium (unterster Jura) des Kanonenberges bei Halberstadt (Deutschland): Beringeria, v. 41, p. 3-24.

Gründel, J., and Nützel, A., 1998, Gastropoden aus dem oberen Pliensbachium (Lias $\delta_{2}$, Zone des Pleuroceras spinatum) von Kalchreuth östlich Erlangen (Mittelfranken): Mitteilungen der Bayerischen Staatssammlung für Paläontologie und Histor. Geologie, v. 38, p. 63-96.

Gründel, J., and Nützel, A., 2012, On the early evolution (Late Triassic to Late Jurassic) of the Architectibranchia (Gastropoda: Heterobranchia), with a provisional classification: N. Jb. Geol. Paläont. Abh., v. 264, p. 31-59.

Haas, O., 1953, Mesozoic Invertebrate Faunas of Peru: New York, Bulletin of the American Museum of Natural History, $321 \mathrm{p}$.

Haszprunar, G., 1985, The Heterobranchia - a new concept of the phylogeny of the higher Gastropoda: Zeitschrift für zoologische Systematik und Evolutionsforschung, v. 23, p. 15-37.

Haszprunar, G., 1988, On the origin and evolution of major gastropod groups, with special reference to the Streptoneura: Journal of Molluscan Studies, v. 54, p. 367-441.

Hébert, E., and Eudes - Deslongchamps, E., 1860, Mémoire sur les fossiles de Montreuil - Bellay (Maine - et - Loire). 1re. partie. Céphalopodes et Gastéropodes: Bulletin de la Société linnéenne de Normandie, v. 5, p. 153-240.

Hornes., R., 1884, Elemente der Palaeontologie (Palaeozoologie): Von Veit and Co., Leipzig, $594 \mathrm{p}$.

Jaworski, E., 1926a, La fauna del Lias y Dogger de la Cordillera Argentina en la parte meridional de la provincia de Mendoza: Actas de la Academia Nacional de Ciencias (Córdoba), v. 9, p. 137-316.

Jaworski, E., 1926b, Beiträge zur Paläontologie und Stratigraphie des Lias, Doggers, Tithons und der Unterkreide in der Kordilleren im Süden der Provinz Mendoza (Argentinien). Teil I. Lias und Dogger: Geologische Rundschau, v. 17 , p. 373-427.

Kaim, A., 2004, The evolution of conch ontogeny in Mesozoic open sea gastropods: Palaeontologia Polonica, v. 62, p. 3-183.

Kaim, A., Beisel, A., and Kurushi, N., 2004, Mesozoic gastropods from Siberia and Timan (Russia), part 1: Vetigastropoda and Caenogastropoda (exclusive of Neogastropoda): Polish Polar Research, v. 25, p. 241-266.

Kase, T., 1984, Early Cretaceous Marine and Brackish-water Gastropoda from Japan: National Science Museum, Tokyo, Japan, 199 p.

Kuhn, O., 1936, Die Fauna des Amaltheentons (Lias $\delta$ ) in Franken: Neues Jahrbuch für Geologie und Paläontologie, v. 75, p. 231-311.

Laube, G.C., 1867, Die Gastopoden des braunen Jura von Balin: Denkscriften der kaiserlichen Akademie der Wissenschaften, v. 28, p. 1-28.

Lindberg, D.R., 1986, Radular evolution in the Patellogastropoda: American Malacological Bulletin, v. 4, p. 115.

Milne-Edwards, H., 1848, Note sur la classification naturelle des mollusques gastéropodes: Annales des Sciences Naturelles Zoologiques, v. 3, p. $102-112$.

Möricke, W., 1894, Versteinerungen des Lias und Unteroolith von Chile: Neues Jahrbuch für Mineralogie, Geologia und Paläontologie B.B, v. 9, p. $1-100$.

Pictet, F. J., and Campiche, G., 1861-1864, Description des fossiles du terrain Crétacé des environs de Sainte-Croix, in Pictet F. J., ed., Matériaux pour la Paléontologie Suisse, v. 2, p. 1-752.

Piette, E., 1856, Sur les coquilles voisines des Purpurines trouvées dans la Grande Oolithe des Ardennes et de l'Aisne: Bulletin de la Société géologique de France, v. 13, p. 587-600.

Ponder, W.F., and Lindberg, D.R., 1997, Towards a phylogeny of gastropod molluscs: an analysis using morphological characters: Zoological Journal of the Linnean Society, v. 119, p. 83-265.

Riccardi, A.C., 2008a, The marine Jurassic of Argentina: a biostratigraphic framework: Episodes, v. 31, p. 326-335.

Riccardi, A.C., 2008b, El Jurásico de Argentina y sus amonites: Revista de la Asociación Geológica Argentina, v. 63, p. 625-643.

Riccardi, A.C., Damborenea, S.E., Manceñido, M.O., and Leanza, H.A., 2011 Megainvertebrados del Jurásico y su importancia geobiológica, in Leanza, H.A., Arregui, C., Carbone, O., Danieli, J.C., and Vallés, J.M., eds., Geología y Recursos Naturales de la Provincia del Neuquén: Relatorio del $18^{\circ}$ Congreso Geológico Argentino Argentina, p. 441-464.

Stoliczka, F., 1861, Über die Gastropoden und Acephalen der Hierlatz-Schichten: Sitzungsberichte der matematisch-naturwissenschaftliche Classe der kaiserlich-königlichen Akademie der Wissenschaften, v. 43, p. 157-204. 
Swainson, W., 1840, A treatise on malacology or shells and shell-fish: London, Longman, $499 \mathrm{p}$.

Szabó, J., 2009, Gastropods of the Early Jurassic Hierlatz Limestone Formation part 1: a revision of type collections from Austria and Hungarian localities: Fragmenta Palaeontologica Hungarica, v. 26, p. 1-108.

Szabó, J., and Jaitly, A.K., 2004, Contributions to the Jurassic of Kachchh, western India VIII. The gastropod fauna. Part II: Discohelicidae, Neritomorpha, Caenogastropoda: Fragmenta Palaeontologica Hungarica, v. 22, p. 9-26.

Tate, R., 1869, Contributions to Jurassic Palaeontology. 1. Cryptaulax, a new Genus of Cerithiadae: The Annals and Magazine of Natural History, v. 4, p. $417-419$.

Terquem, O., 1855, Paléontologie de l'étage inferieur de la formation liassique de la province de Luxembourg, Grand-Duché (Hollande) et de Hettange, du department de la Moselle: Mémoires de la Société Géologique de France, v. 5 , p. $219-343$.

von Ammon, L., 1878, Die Gastropoden des Hauptdolomites und des Plattenkalkes der Alpen: Abhandlungen des zoologisch-mineralogischenVereines in Regensburg, v. 11, p. 1-72. von Zittel, K.A., 1895, Grundzüge der Paläontologie (Paläozoologie): München and Leipzig, Abt i. Invertebrata. Oldenburg, $971 \mathrm{p}$.

Wahnish, E., 1942, Observaciones geológicas en el Oeste del Chubut. Estratigrafia y fauna del Liásico en los alrededores del rio Genua: Boletin del Servicio Geológico Nacional, v. 51, p. 1-73.

Weaver, C., 1931, Paleontology of the Jurassic and Cretaceous of West Central Argentina: Memoir, University of Washington, v. 1, p. $1-469$.

Wenz, W., 1938-1944, Gastropoda. Prosobranchia, in Schindewolf, O.H., ed. Handbuch der Paläozoologie, Band 6: Berlin, Verlag von Gebrüder Borntraeger, p. 1639.

Zapfe, H, 1962, Beiträge zur Paläontologie der nordalpinen Riffe. Ein Massenvorkommen von Gastropoden im Dachsteinkalk des Tennengebirges, Salzburg: Annalen des Naturhistorischen Museums Wien, v. 65, p. $57-69$.

Accepted 23 August 2016 